\title{
Exploring the Use of Molecular Biomarkers for Precision Medicine in Age-Related Macular Degeneration
}

\author{
Laura Lorés-Motta ${ }^{1}$ Eiko K. de Jong ${ }^{1}$ Anneke I. den Hollander ${ }^{1,2}$
}

Published online: 26 April 2018

(C) The Author(s) 2018

\begin{abstract}
Precision medicine aims to improve patient care by adjusting medication to each patient's individual needs. Age-related macular degeneration (AMD) is a heterogeneous eye disease in which several pathways are involved, and the risk factors driving the disease differ per patient. As a consequence, precision medicine holds promise for improved management of this disease, which is nowadays a main cause of vision loss in the elderly. In this review, we provide an overview of the studies that have evaluated the use of molecular biomarkers to predict response to treatment in AMD. We predominantly focus on genetic biomarkers, but also include studies that examined circulating or eye fluid biomarkers in treatment response. This involves studies on treatment response to dietary supplements, response to anti-vascular endothelial growth factor, and response to complement inhibitors. In addition, we highlight promising new therapies that have been or are currently being tested in clinical trials and discuss the molecular studies that can help identify the most suitable patients for these upcoming therapeutic approaches.
\end{abstract}

Anneke I. den Hollander

anneke.denhollander@radboudumc.nl

1 Department of Ophthalmology, Donders Institute for Brain, Cognition and Behaviour, Radboud University Medical Centre, Philips van Leydenlaan 15, 6525 EX Nijmegen, The Netherlands

2 Department of Human Genetics, Donders Institute for Brain, Cognition and Behaviour, Radboud University Medical Center, Nijmegen, The Netherlands

\section{Key Points}

Current work on genetic and molecular biomarkers for treatment response in age-related macular degeneration (AMD) is still exploratory, and precision medicine for AMD is not yet ready for implementation in the clinic.

Several genetic and molecular biomarkers that associate with response to anti- vascular endothelial growth factor therapy have been identified, but these associations have not been consistently replicated.

Studies on complement system biomarkers may be useful to identify patients for complement-inhibiting therapies that are currently under development.

\section{Introduction}

Precision medicine aims to improve healthcare through individualized selection of treatment options, taking into account each patient's characteristics and individual needs. Biomarkers defining individual patient characteristics can be used in a clinical setting to define individualized screening strategies, recommend personalized preventions, select the best therapy for individual patients, tailor the dosing of medication, and can help avoid patients being given unnecessary treatments that they will not benefit from or might even be harmful. The field of precision medicine has moved forward rapidly in the last few decades thanks to the identification of genetic markers that 
predict response to treatment in many different diseases [1]. Genetic screening prior to treatment is now increasingly being implemented in the healthcare system [2-4]. A prime example is the oncology field, where, for instance, genetic variants in the DPYD gene are highly recommended to be screened to avoid toxicity from fluoropyrimidine drugs [5]. Other examples include the anticoagulant warfarin, for which genotype-guided prescription has been established to improve safety and effectiveness, and to reduce healthcare costs [6-8]. Besides genetic markers, other biomarkers such as metabolites are also being explored for clinical utility in precision medicine [9].

In the field of ophthalmology, the potential of precision medicine is actively being investigated. The focus of this review is age-related macular degeneration (AMD), the most common cause of blindness in the elderly in the Western world, and the third most common cause of severe visual impairment worldwide $[10,11]$. The increased ageing of the population is boosting the number of affected individuals, which is expected to reach 196 million by 2020, therefore posing a major and rising burden on healthcare [12]. AMD is a progressive disease that affects the macula, which is located in the center of the retina, and is responsible for central vision, color vision and sharp vision. In early stages, AMD is characterized by the occurrence of drusen, which are deposits of extracellular debris that accumulate underneath the retinal pigment epithelium (RPE), the cell layer supporting the neurosensory retina [13]. During the course of the disease, drusen increase in number and size, and AMD can progress into advanced stages in which vision loss occurs. These advanced stages can be divided in two types: geographic atrophy (GA) and choroidal neovascularization (CNV). GA is characterized by atrophy of the retina, resulting from gradual loss of photoreceptors, RPE cells and the choriocapillaris [14]. CNV, also referred to as neovascular AMD (nvAMD), involves the abnormal growth of blood vessels from the choriocapillaris invading the retina, with subsequent leakage and bleeding, and provokes a vision-threatening scar in the macula. The prevalence of both advanced types is similar, and both types of the disease cause visual loss [12]; however, nvAMD accounts for most of the visual acuity loss caused by AMD [15].

AMD is a complex heterogeneous disease in which genetic factors as well as environmental factors contribute to disease risk. Genetic factors play a major role in the disease etiology, explaining up to $71 \%$ of the disease variation [16]. The first single-nucleotide polymorphisms (SNPs) found to be associated with AMD were rs1061170 in $C F H$ and rs 10490924 in $A R M S 2$ [17, 18]. In a recent genome-wide association study (GWAS), 52 independent genetic variants across 34 loci were identified to influence AMD disease risk [19]. These genetic associations have implicated the complement system, lipid metabolism, extracellular matrix remodeling and angiogenesis in the disease process [19]. Age is the most important demographic risk factor for AMD development, and other factors that have consistently been described to influence the disease risk are cigarette smoking, previous cataract surgery and family history of AMD [20].

Currently, only advanced nvAMD can be treated, by targeting vascular endothelial growth factor (VEGF). For GA, although several therapies are actively being developed, no established treatment is available to date. Also, progression of the disease cannot be halted, but it can be slowed down with the use of nutritional supplements.

Due to the heterogeneity in the AMD patient population, it is plausible that the effect of therapeutic interventions depends on the biological drivers of disease in each individual patient. In essence, the patient's genetic blueprint, in addition to demographic and lifestyle factors, is likely to influence how a patient responds to treatment. Consequently, the identification of biomarkers that can predict response to therapy in AMD could be used to improve AMD patient care, by tailoring medication to each patient's individual needs.

In this review, we aim to provide an overview of the current literature investigating the association of biomarkers with response to supplements and anti-VEGF therapy, as well as to describe new therapeutic approaches undergoing clinical trials and the potential use of biomarkers for patient selection.

\section{Current Therapeutic Interventions for Age- Related Macular Degeneration Management}

\subsection{Dietary Supplements for Slowing Disease Progression}

Dietary supplementation with vitamins and zinc is proven to reduce the risk of progression to advanced AMD. These supplements act against oxidative stress, which is thought to be one of the drivers of AMD pathogenesis [21, 22]. Oxidative stress refers to a disturbance in the balance between the production of reactive oxygen species and antioxidant defenses. The retina is highly susceptible to oxidative stress due to sunlight exposure, high oxygen consumption and high concentration of polyunsaturated fatty acids. Moreover, oxidative stress increases with age and is associated with smoking, another AMD risk factor [22]. The notion that oxidative stress may play an important role in AMD development and progression led to the development of the Age-Related Eye Disease Study (AREDS) clinical trial that evaluated the effect of high doses of vitamin $\mathrm{C}$, vitamin $\mathrm{E}$, beta-carotene and zinc on 
AMD progression. In 2001, the AREDS trial concluded that patients with intermediate AMD in at least one eye receiving this formulation reduced their risk of progression to advanced AMD by $25 \%$ at 5 years [23]. An AREDS 2 supplementation trial followed in 2013, describing an improved formula with lutein and zeaxanthin substituting beta-carotene. This formula showed the same effects, but is preferred as beta-carotene conferred risk for lung cancer in former smokers [24]. Clinicians have rapidly adopted the AREDS recommendations, and the oral use of antioxidants combined with zinc is currently prescribed for intermediate or unilateral advanced AMD.

AMD-associated variants have been found to influence AMD progression, and for several years, there have been investigations into whether specific genotypes interact with the AREDS supplementation, affecting progression rates [25]. These studies sparked an intense debate in the field as different research groups arrived at different conclusions. In 2008, Klein et al. suggested that response to AREDS supplements could be related to the $C F H$ rs 1061170 genotype [26]. The study evaluated 876 AREDS patients and found that for carriers of the CC genotype, dietary supplementation would have a smaller effect, possibly related to zinc consumption, but would still be beneficial. No interaction was found for the ARMS2 rs10490924 SNP. In 2013, a second study that included 995 AREDS participants was published by Awh et al., also proposing a genotypic interaction [27] and suggesting that improved outcomes could be obtained after genotype selection. The authors described a deleterious interaction between $\mathrm{CFH}$ risk alleles (rs412852 and rs3766405) and supplementation with zinc, in which carriers of $C F H$ risk alleles would progress to advanced AMD faster when taking zinc. Also, the authors claimed that individuals homozygous for the CFH and ARMS2 risk alleles would not benefit from the AREDS formula. After these results, the AREDS Research Group attempted replication in a larger AREDS cohort of 1237 AMD patients, but did not identify any interaction, and concluded that reduction in the risk of AMD progression after supplementation was seen in all genotype groups [28]. This study was followed by a series of contradictory results [29-31] and intense argumentation [32-34]. In a recent report, independent statistical research groups analyzed the data from the AREDS Research Group and from Awh and colleagues. Errors in the Awh et al. 2013 study were noted, and no interaction was reported between the $C F H$ and ARMS2 SNPs and treatment response after correction for multiple testing. Therefore, it was concluded that AMD patients should be offered dietary supplementation regardless of genotype [35]. The most recent study performed multiple statistical analyses on an extended AREDS dataset of 802 individuals and suggested that the response to AREDS formulation treatment varies substantially among individuals, based on $C F H$ and ARMS2 genotypes. This study therefore concludes that the use of the AREDS formulation should be based on patientspecific genotypes [36].

\subsection{Anti-VEGF Antibodies for Choroidal Neovascularization Treatment}

The gold-standard treatment for nvAMD consists of intravitreal injections of anti-VEGF antibodies. VEGFA is the master regulator of angiogenesis and leads to proliferation, migration and survival of vascular endothelial cells, as well as to vascular permeability [37, 38]. In the AMD disease process, hypoxia, oxidative stress and activation of the complement system promote VEGFA secretion by the RPE, which will eventually lead to abnormal CNV formation [39-41]. Anti-VEGF antibodies block VEGFA binding to its receptors and thus inhibit its angiogenic effects.

Anti-VEGF antibodies for nvAMD treatment include ranibizumab (Lucentis; Novartis, Basel, Switzerland, and Genentech Inc., South San Francisco, USA), bevacizumab (Avastin, Genentech, South San Francisco, USA), and aflibercept (EYLEA, Regeneron Pharmaceutical Inc., Tarrytown, USA). Bevacizumab has been approved by the Food and Drug Administration (FDA) for the treatment of several cancer types; however, it is administered off label for the treatment of nvAMD. The CATT and IVAN clinical trials demonstrated similar outcomes after bevacizumab treatment compared to ranibizumab [42-45]. The administration of these agents usually consists of a loading dose of three monthly injections followed-up with a variable treatment regimen.

The use of anti-VEGF drugs to treat nvAMD has significantly changed the prognosis of the disease and has led to significant improvements in visual acuity. Nevertheless, a more detailed analysis of individual patient outcomes shows that not all patients benefit equally from the therapy. Vision remains stable or improves in approximately $80 \%$ of the patients, but approximately $20 \%$ of treated patients continue to lose vision despite treatment [46, 47]. Along the same line, anatomical changes in the retina after treatment, reflecting fluid clearance, are also variable among patients [42].

Understanding the reasons underlying this variability in treatment outcome can help improve treatment strategies, would allow early identification of poor responders, and would enable individual treatment optimization. Clinical and epidemiological factors that have repeatedly been associated with worse treatment outcome include baseline parameters such as older age, larger CNV lesion, larger retinal tissue thickness and lower visual acuity [48]. These factors are highly correlated and indicative of longer 
disease duration, highlighting the importance of initiating treatment in an early phase. Nevertheless, these factors cannot fully explain the wide range in treatment outcomes [49]. Due to the highly heritable nature of AMD, it has been hypothesized that genetic factors may influence treatment outcome. Genetic markers are independent of disease duration and therefore may explain treatment outcome variability.

Since the first publication in 2007 [50], a vast number of studies have investigated associations of genetic variants with anti-VEGF treatment outcome in nvAMD. We reviewed the pharmacogenetic studies published to date and provide a detailed overview of their study designs and conclusions in Table 1. Despite the large body of literature on this topic, with over 50 studies published, solid conclusions cannot be drawn. This is due to conflicting results and a high heterogeneity in study designs, which makes comparisons between studies challenging. Studies may involve ranibizumab treatment, bevacizumab treatment or both. Moreover, the definition of treatment response is highly variable: change in visual acuity, change in total retinal thickness, CNV recurrence or number of injections are some of the variables used to measure treatment outcome. These variables are analyzed in a continuous or in a categorical manner, in which responders are compared to non-responders based on an arbitrary definition of response. Additionally, the studies evaluate response after the loading dose of three monthly injections or longer and may therefore involve different treatment protocols. Also, correction for multiple testing is not applied in all studies, and the majority of studies do not provide a statistical power calculation.

At the onset of the field of pharmacogenetics in AMD, a natural target to explore was the main genetic variant associated with AMD: SNP rs1061170 in the $C F H$ gene. Indeed, most of the studies have investigated this SNP; however conflicting results have been reported. Several studies have reported an association of this genetic variant with response to anti-VEGF treatment [50-63]; in all instances, the AMD-risk-conferring allele (C) led to a worse outcome after therapy. However, others have not identified any association [64-78]. Three different metaanalyses have been carried out, all showing an association of rs1061170 with treatment response with a moderate level of significance [79-81]. The most recent and comprehensive study included a total of 2963 individuals from 14 different studies and showed that patients homozygous for the AMD low-risk allele (T) were more likely to have a better outcome compared to patients homozygous for the AMD high-risk allele $(\mathrm{C})$ [odds ratio $(\mathrm{OR})=1.932,95 \%$ confidence interval (CI) 1.125-3.173, $P=0.017$ ] [81]. Notably, the two studies based on the IVAN and CATT clinical trials did not find any association for this variant, nor for any other variant investigated, despite their large sample sizes ( $n=834$ and $n=509$, respectively) [71, 72].

The SNPs in ARMS2/HTRAl (rs10490924 and rs11200638, which are in high linkage disequilibrium) [82] have also been widely evaluated for association with treatment outcome. A similar scenario emerged for these SNPs, where several studies reported an association in which the AMD-risk allele leads to worse response $[59,64,67,69,70,75,77,83]$, while others do not report an association [50, 52, 59, 60, 62, 65, 68, 71-73, 78, 84-87]. As an exception, Kang and colleagues described that carriers of the AMD-risk allele in rs10490924 needed fewer bevacizumab injections after the loading dose [57]. A metaanalysis including 2389 cases from 12 studies showed that patients homozygous for the AMD low-risk allele in ARMS2 rs10490924 (GG) have a higher chance of responding better to treatment compared to patients heterozygous (TG) or homozygous (TT) for the AMD high-risk allele $(\mathrm{OR}=1.34$, 95\% CI 1.01-1.77, $P=0.039$ ), although no significant difference was found on the allele level. Also, no differences were found when the analysis was limited to patients of European descent [88]. Another meta-analysis of 1570 cases from five studies showed no association for the SNP rs11200638 [89]. Most study designs evaluated treatment outcome after 3-12 months of treatment, but a recent study evaluated the effect of genetic variants after 4 years of antiVEGF treatment. This study by Valverde-Megías et al. examined the rs 1061170 CFH and rs10490924 ARMS2 SNPs and reported that patients homozygous for the AMD-risk allele of the ARMS2 SNP required more injections over this long-term follow-up period [77].

Due to the nature of anti-VEGF therapy, the VEGFA gene and the $K D R$ gene, encoding the main receptor for VEGFA, were also considered candidates to be involved in anti-VEGF treatment response. Most of the SNPs investigated in these genes have recently been evaluated in a meta-analysis. After evaluation of nine SNPs (rs699947, rs699946, rs833069, rs833061, rs2146323, rs1413711, rs2010963 and rs 1570360 in VEGFA, and rs2071559 in KDR), anti-VEGF treatment was found to be more effective in patients homozygous for the VEGFA rs833061 minor allele $\mathrm{C}$, compared to the remaining AMD patients $(\mathrm{OR}=2.362,95 \%$ CI 1.41-3.95, $P=0.001)$. This analysis was, however, limited in sample size, including only 444 AMD patients from three independent studies [90]. An SNP (rs2070296) in the neuropilin-1 (NRPl) gene, encoding the co-receptor for VEGF, has been associated with worse response to treatment in one study [91], but this SNP has not yet been evaluated in independent cohorts. Other reported associations with treatment response include the APOE $\varepsilon 4$ allele [92, 93], IL8 rs4073 [59, 73, 94], and $P E D F$ rs1136287 [52], which have been analyzed in only a limited number of studies and warrant replication analyses. 


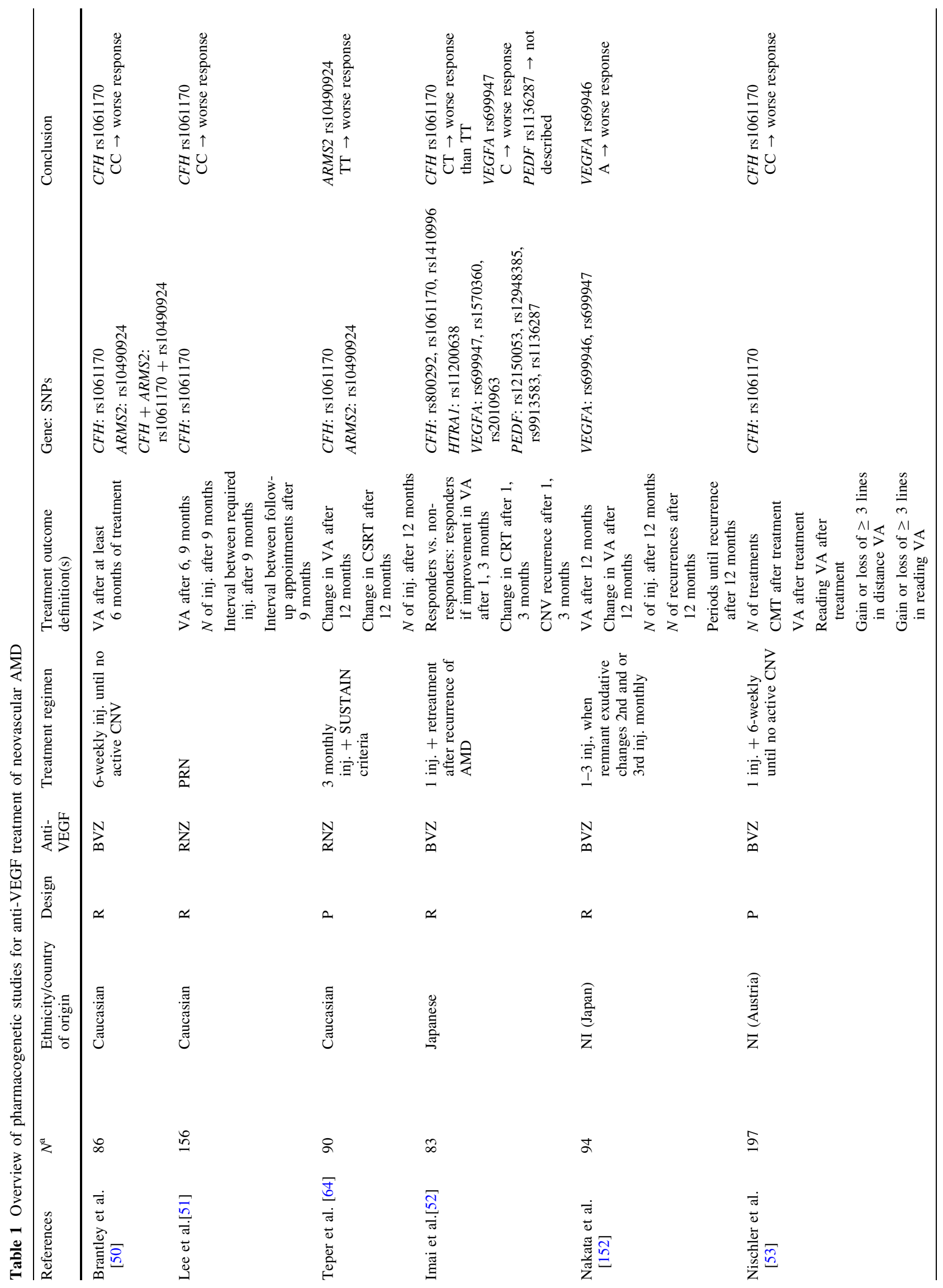




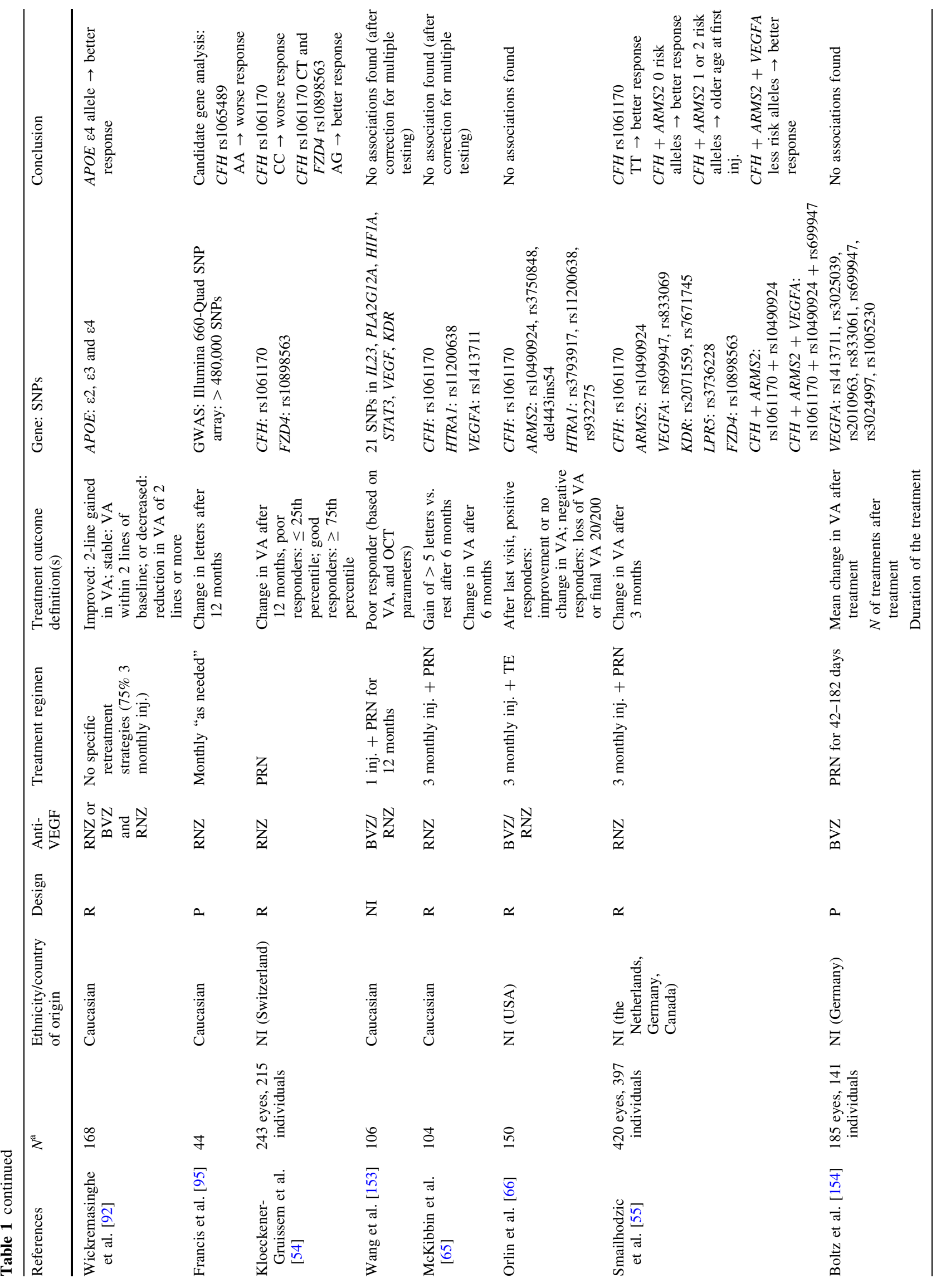




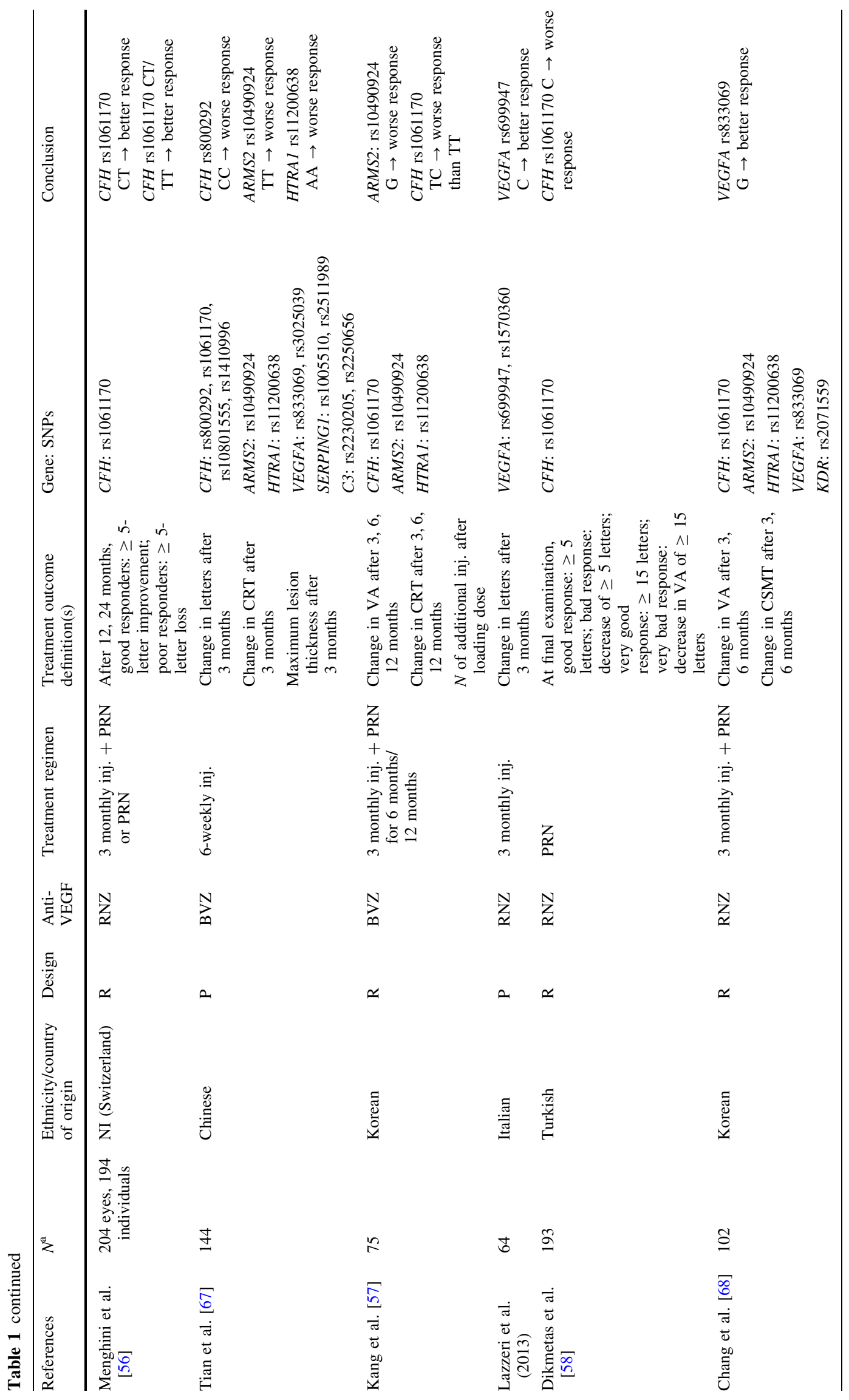




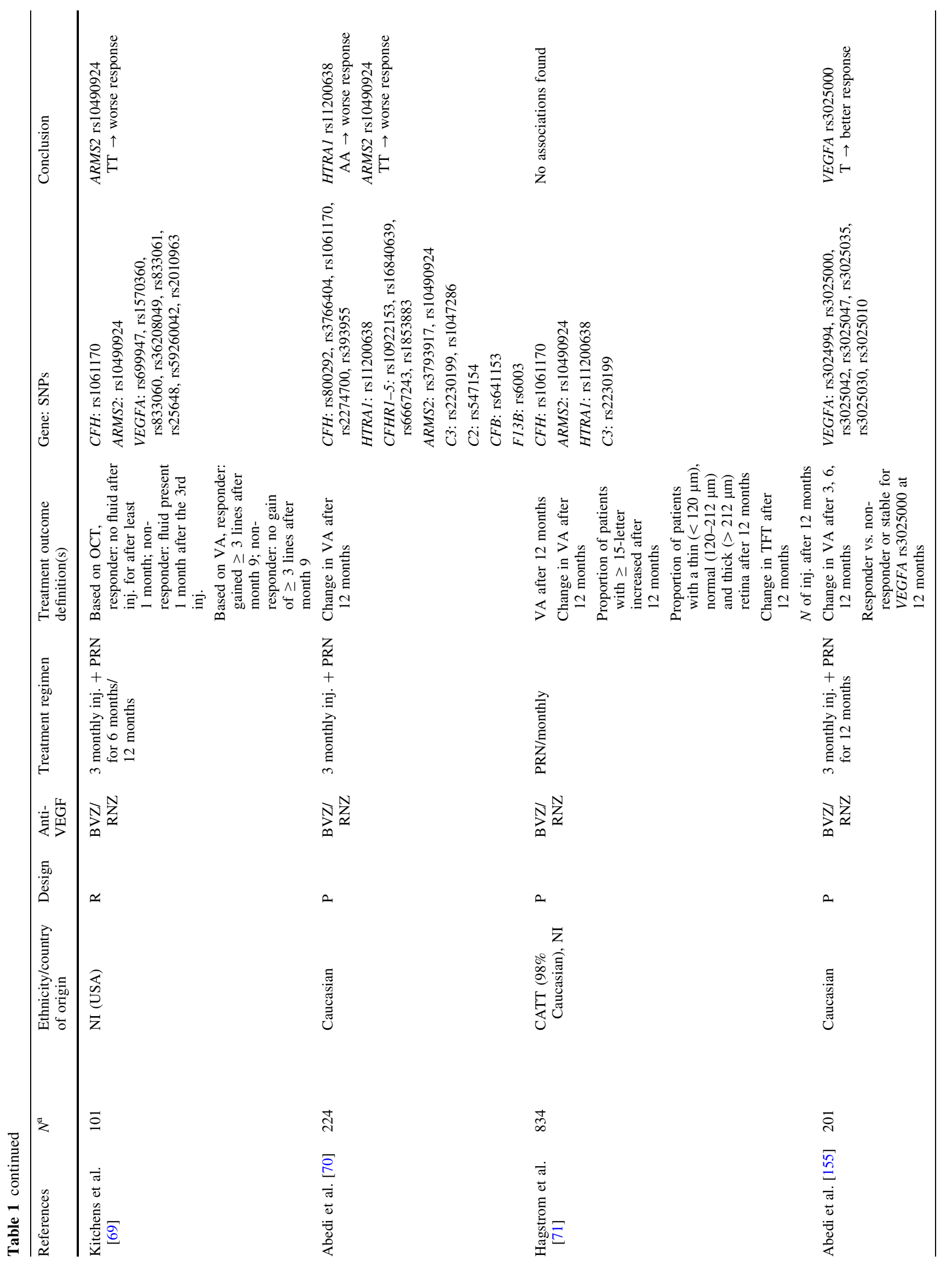




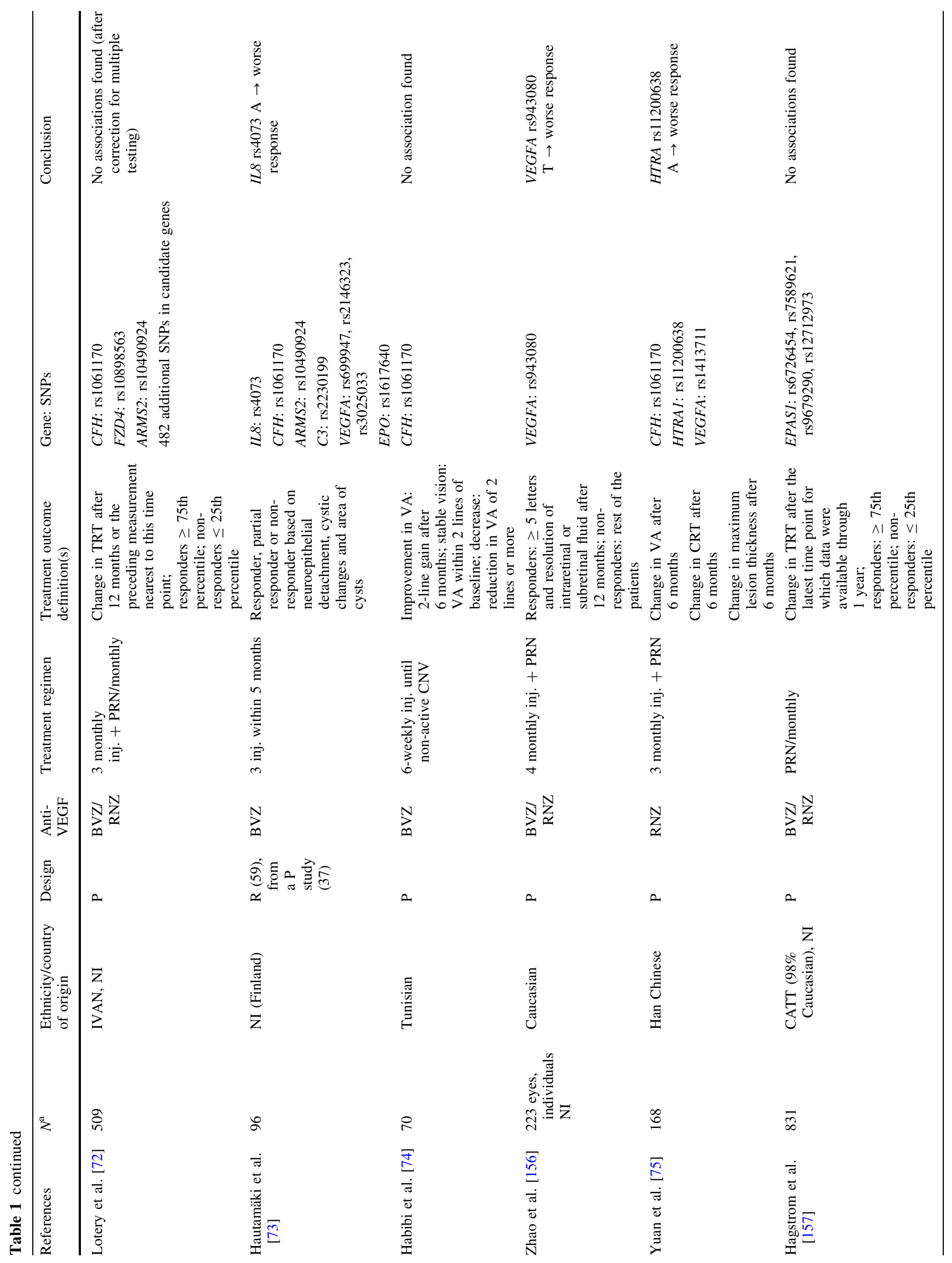




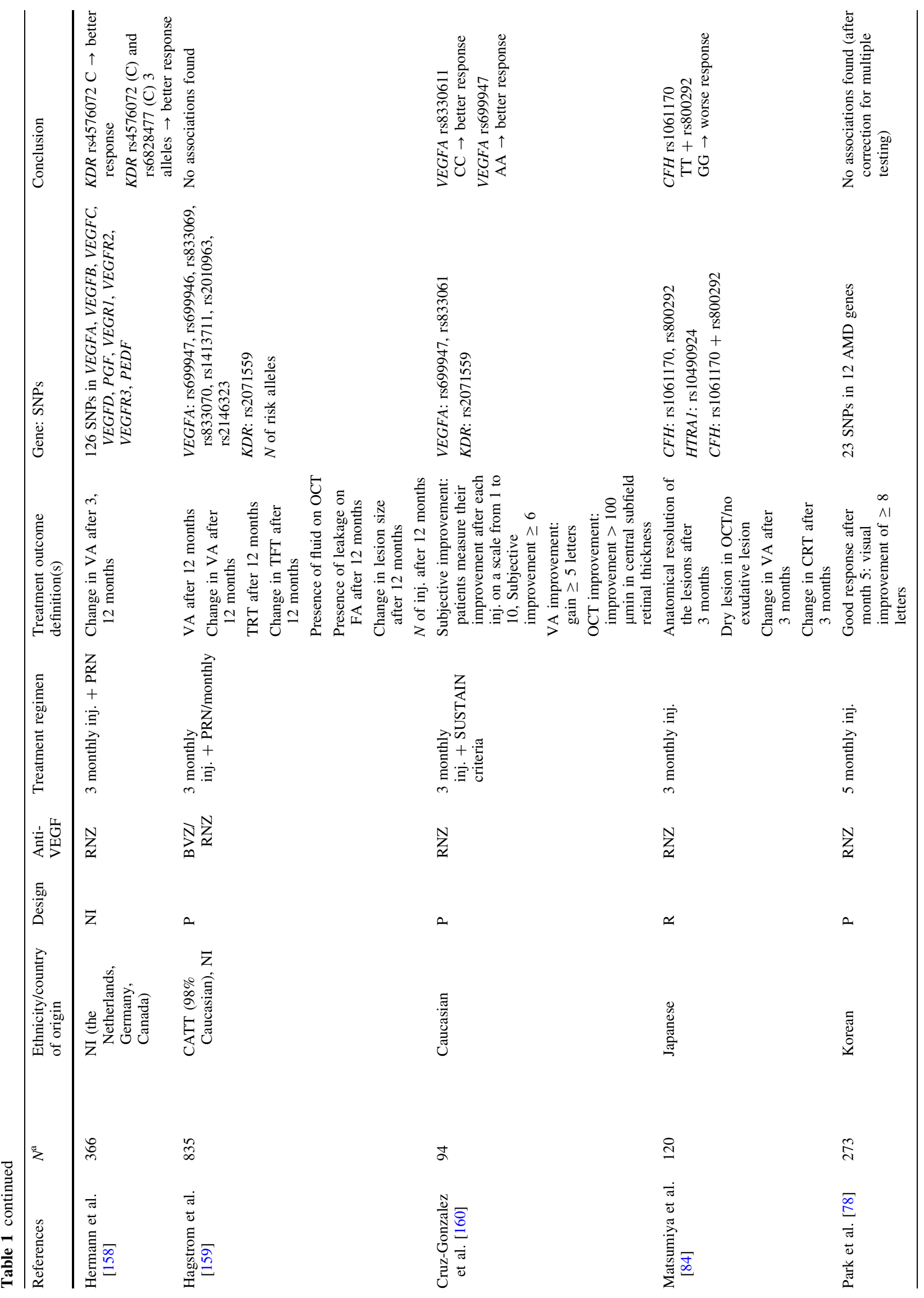




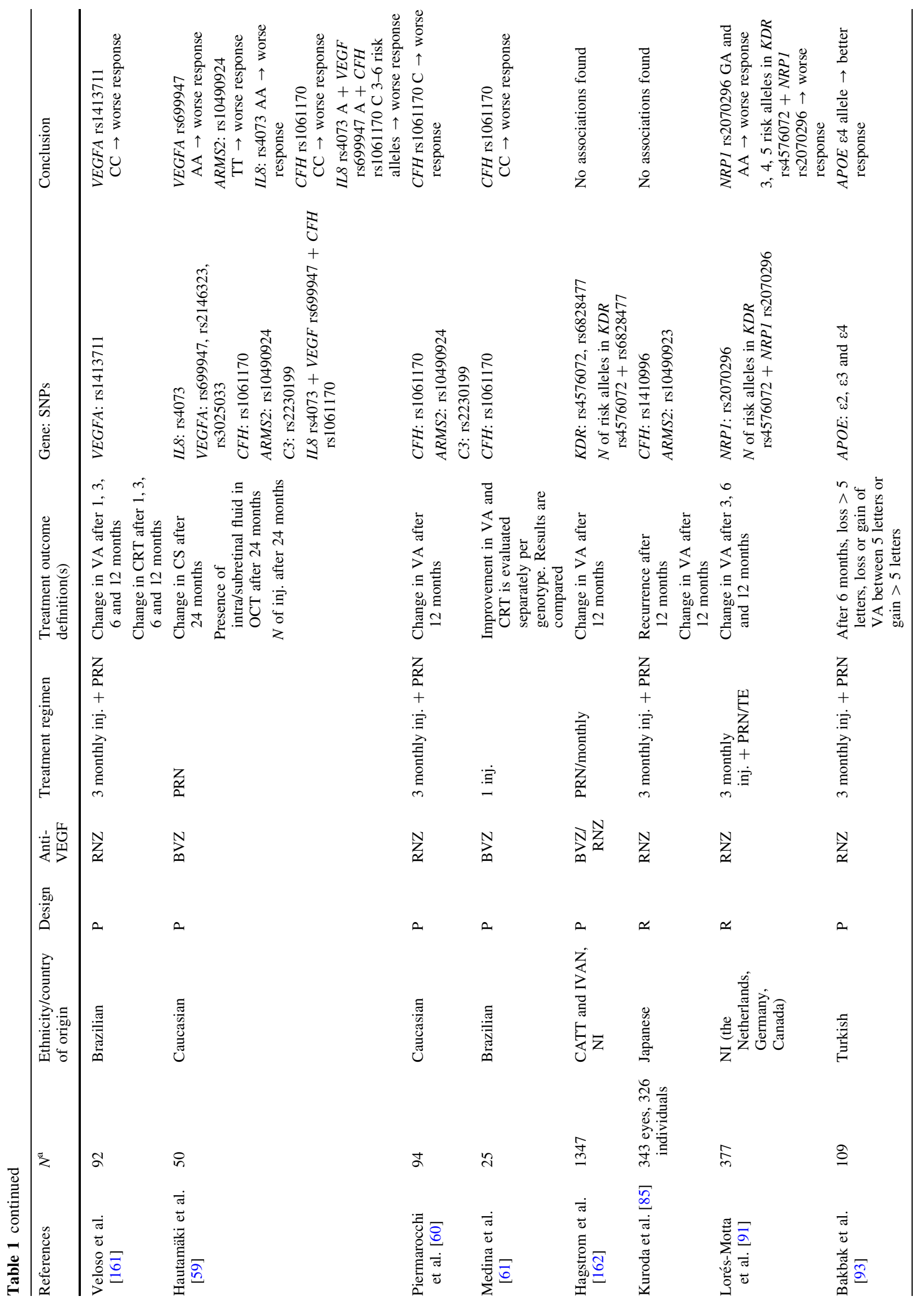




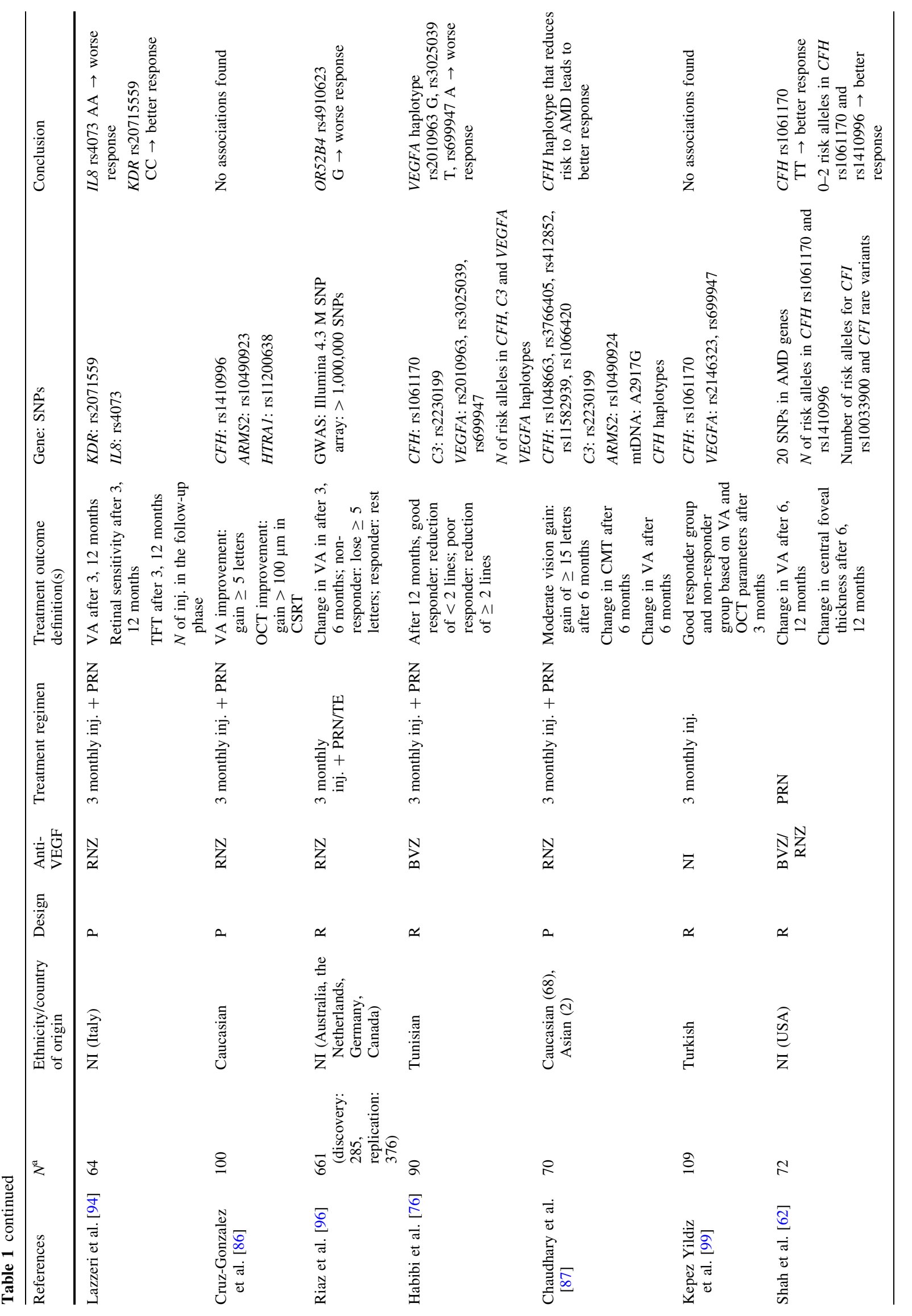




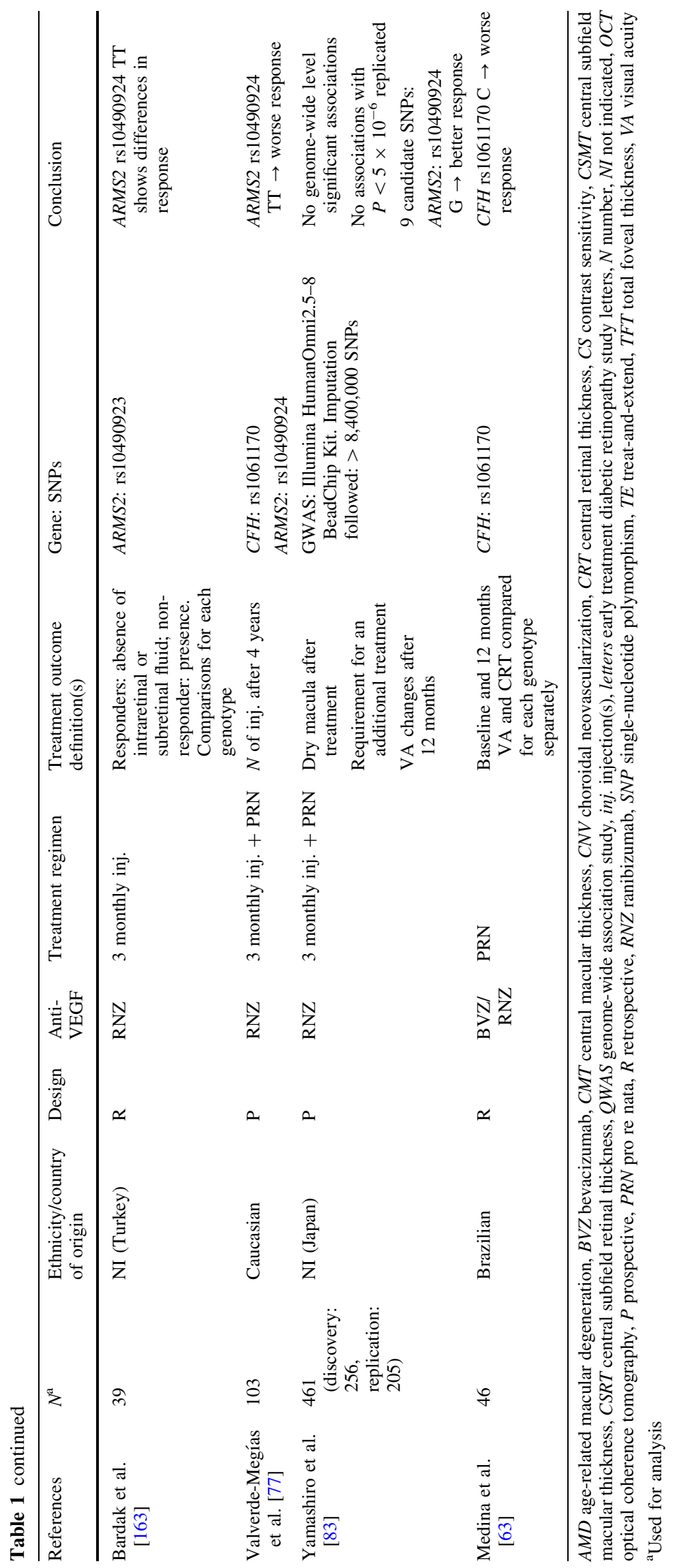


The aforementioned variants have been examined in candidate gene/variant studies because of their known role in AMD or the neovascularization process. In contrast, GWASs examine genetic variation across the whole genome in a hypothesis-free approach. Three GWASs for antiVEGF treatment response have been published to date $[83,95,96]$. The first study, by Francis, involved only 65 AMD patients. When evaluating only candidate genes, an association with visual acuity outcome was reported for CFH rs1065489, and an association with change in macular thickness was reported for $C 3$ rs2230205 [95]. In the second study, Riaz and colleagues included a total of 673 AMD patients and, after replication in an independent cohort, described rs4910623 located in the olfactory receptor gene $O R 52 B 4$ as a new variant associated with worse treatment outcome [96]. The last study by Yamashiro et al. analyzed 461 AMD patients collected in a prospective study design, and in a discovery and replication setting. The discovery GWAS phase in 256 patients did not identify any genome-wide associations, and suggestive associations could not be replicated. In a candidate SNP analysis that included nine variants, ARMS2 rs10490924 G was associated with additional treatment requirement after the loading dose [83].

In addition to the pharmacogenetic studies, other biomarkers have also been described to be associated with anti-VEGF treatment response in nvAMD. In aqueous humor, VEGF and interleukin-6 (IL-6) levels have been measured prior to treatment, and they seem to be indicative of the outcome. Lai and colleagues reported that baseline aqueous VEGF levels associated with persistent angiographic leakage after 3 months of bevacizumab therapy [97]. In another study, by Chalam and colleagues, correlations of VEGF and IL-6 levels with change in central subfield macular thickness after three monthly injections of bevacizumab treatment were described, with the correlation of IL-6 levels being the strongest [98].

Studies in plasma and serum have also suggested potential systemic biomarkers. Kepez Yildiz et al. described higher levels of plasma IL-6 in good responders compared to non-responders [99]. Nassar and colleagues evaluated 16 inflammatory cytokines and found that high IL-17 and tumor necrosis factor- $\alpha$ (TNF- $\alpha$ ) serum levels were associated with favorable response to anti-VEGF therapy [100]. Lechner et al. described that plasma complement component (C3a) levels were elevated in partial responders compared to complete responders; no differences were found for $\mathrm{C} 4 \mathrm{a}$ and $\mathrm{C} 5 \mathrm{a}$ levels [101]. Additionally, Kubicka-Trzaska and colleagues analyzed serum anti-retinal antibodies and reported that a decrease in antiretinal antibodies levels after bevacizumab treatment correlated with functional and anatomical response [102].

\section{Therapies in Clinical Trials}

\subsection{Complement-Inhibiting Therapies}

Anti-VEGF treatment is currently only indicated for nvAMD, which affects only half of the advanced AMD patients. For the other half, who suffer from GA, no treatment is available yet. Current research and development efforts are heavily focused on this category of patients, and genetic and physiological associations are used to identify targets for therapy. Based on this, a prime candidate target in AMD is the complement system, an essential component of the immune system. The complement system consists of an intricate proteolytic cascade that leads to inflammation, opsonization and targeted cytolysis through the formation of the membrane attack complex (MAC) (Fig. 1) [103]. Over-activation of the complement system, particularly of the alternative pathway, has been described to be associated with AMD [104]. Consequently, several therapies aiming to inhibit complement activity are being developed. These therapies aim to slow down disease progression and to prevent the development of GA, but may also be useful for nvAMD patients in combination with anti-VEGF drugs.

Complement-inhibiting therapies that have gone through clinical trials include APL-2, lampalizumab, eculizumab, tesidolumab, CLG561, Zimura and AAVCAGsCD59 (also known as HMR59) (Fig. 1a). These drugs inhibit the complement system at different levels of the proteolytic cascade.

APL-2 (Apellis Pharmaceuticals, Crestwood, USA), a reformulated version of POT-4, is a cyclic peptide inhibitor of complement component 3 (C3). This drug is currently being tested in a phase II clinical trial (https://clinicaltrials. gov, NCT02503332). According to Apellis Pharmaceuticals (http://www.apellis.com), this clinical trial has already resulted in a significant reduction in the rate of geographic lesion growth over 12 months. Lampalizumab (Genentech Inc., South San Francisco, CA) is an antigen-binding fragment of a humanized monoclonal antibody that targets complement factor D (FD). The phase II clinical trial for Lampalizumab (MAHALO) has been completed, and yielded promising results with a $20 \%$ reduction in atrophy area progression at month 18 for the monthly treated group compared to placebo [105]. Lampalizumab is currently being evaluated in two phase III clinical trials (SPECTRI and CHROMA, NCT02247531 and NCT02247479, respectively). Recently, Genentech revealed in a press release that SPECTRI did not meet its primary endpoint of reducing mean change in GA lesion area, and that they are expecting the results of CHROMA to be evaluated in November 2017. Eculizumab (Soliris, Alexion 
Fig. 1 Schematic representation of the complement system proteolytic cascade. a Complementinhibiting therapies currently evaluated in clinical trials and their specific targets are presented. The targets of the complement-inhibiting therapies are complement $\mathrm{C} 3$, complement factor D (FD), complement $\mathrm{C} 5$, properdin and CD59. C3 is a central component of the complement cascade, as upon activation, its cleavage leads to the formation of the anaphilatoxin $\mathrm{C} 3 \mathrm{a}$ and to the opsin $\mathrm{C} 3 \mathrm{~b}$. C3b will also form the alternative pathway $\mathrm{C} 3$ convertase and all C5 convertases. FD activates the system through the cleavage of C3b-bound FB to form the alternative pathway convertases. C5 is the second central component of the cascade downstream of C3. Upon cleavage, C5 leads to the anaphylatoxin $\mathrm{C} 5 \mathrm{a}$ and to $\mathrm{C} 5 \mathrm{~b}$, the first component of the membrane attack complex (MAC). Properdin is a positive regulator of the system that stabilizes the alternative pathway convertases (C3bBb). Another inhibitor of the system acting on the terminal pathway is MAC-inhibitory protein (MAC-IP, also known as CD59), which also recognizes host cells, and inhibits the formation of the MAC. A red line towards the target indicates inhibition, whereas a green line indicates augmentation. $\mathrm{C} 4 \mathrm{bC} 2 \mathrm{~b}$ and $\mathrm{C} 3\left(\mathrm{H}_{2} \mathrm{O}\right) \mathrm{Bb}$ are $\mathrm{C} 3$ convertases; $\mathrm{C} 4 \mathrm{bC} 2 \mathrm{bC} 3 \mathrm{~b}$ and $\mathrm{C} 3 \mathrm{bBbC} 3 \mathrm{~b}$ are $\mathrm{C} 5$ convertases. b Upon activation of the complement system, C3b is degraded to $\mathrm{C} 3 \mathrm{~d}$ on the cell surface
A

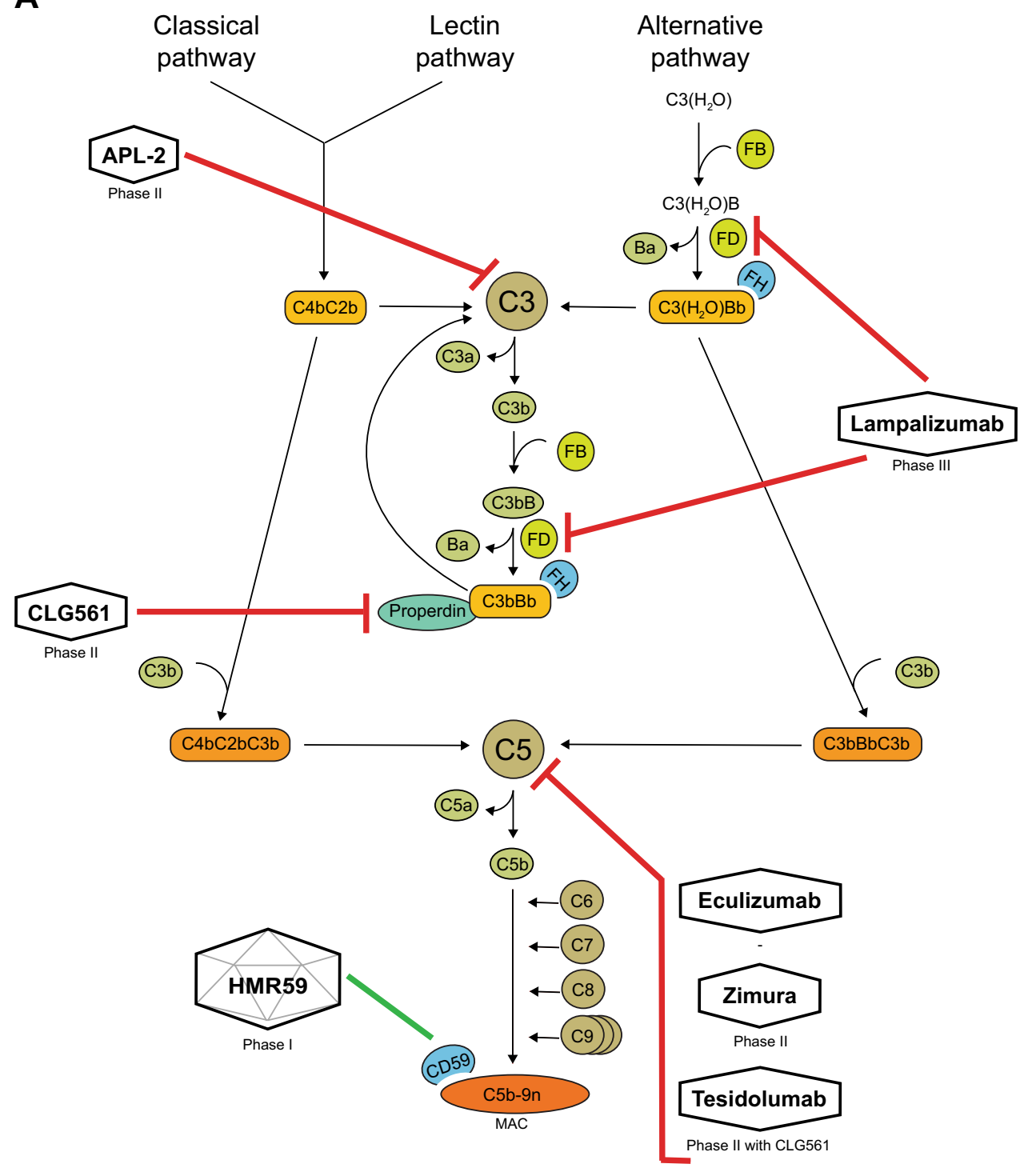

B

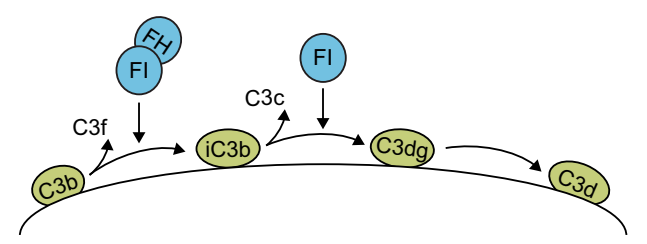

Pharmaceuticals, New Haven, USA) is a humanized monoclonal antibody targeting complement 5 (C5). Eculizumab has been approved for the treatment of paroxysmal nocturnal hemoglobinuria. In a phase II clinical trial in AMD (COMPLETE, NCT00935883), systemically administered eculizumab was well-tolerated; however, it did not decrease the growth rate of GA significantly [106]. Another drug targeting C5 is Zimura (Ophtotech, USA), a chemically synthesized aptamer. This drug is currently in a phase II/III trial (NCT02686658). Tesidolumab (LFG316, Novartis, Basel, Switzerland/MorphoSys, Planegg, Germany) is a human monoclonal antibody also targeting C5. The phase II clinical trial has been completed (NCT015275000); however, the results have not yet been published. Currently, another phase II trial is ongoing which analyzes CLG561 (Novartis, Basel, Switzerland), a 
fully human antibody Fab that neutralizes properdin, as monotherapy or in combination with tesidolumab (NCT02515942). Finally, the first gene therapy tested for GA treatment is HMR59 (AAVCAGsCD59, Hemera Biosciences Inc., Newton, USA), and its safety is currently being evaluated in a phase I clinical trial (NCT03144999). This therapy consists of a single injection of an adenoassociated virus that transfects the retinal cells, leading to expression of a soluble form of MAC-inhibitory protein (MAC-IP, also named CD59). The potential of gene therapies is further described in Sect. 3.2 of this review.

Complement-inhibiting therapies will presumably be most effective in AMD patients in whom the complement system is most over-activated. Several studies have evaluated levels of complement components and activation fragments, which may represent useful biomarkers for treatment response to complement-inhibiting therapies in AMD. Systemic levels of complement activation fragments such as $\mathrm{Ba}, \mathrm{Bb}, \mathrm{C} 3 \mathrm{a}, \mathrm{C} 3 \mathrm{~d}$ and $\mathrm{C} 5 \mathrm{a}$ and the $\mathrm{C} 3 \mathrm{~d} / \mathrm{C} 3$ ratio, as well as levels of complement components FB and FD seem to be elevated in AMD patients compared to controls [107-113]. Systemic levels of complement component C3 and FI levels, however, appear not to differ between AMD patients and controls [108, 109, 111, 113-115]. FH levels have been reported to be lower in AMD in some studies [116, 117], but others do not report a difference [108, 109, 113, 114, 118]. Specific complement levels could therefore be used to identify AMD patients with high levels of complement activity. Nevertheless, a high variability in these complement markers is found within the AMD and control groups, and the levels show a large overlap between cases and controls. Consequently, other markers may be useful as well to predict response. In a recent study including 31 nvAMD patients and 30 controls, aqueous humor differences in $\mathrm{Ba}$ and $\mathrm{C} 3 \mathrm{a}$ levels were detected, whereas plasma differences were not, probably due to the limited sample size. These results suggest that differences in complement activation levels between patients and controls are larger locally in the eye compared to systemically [119].

Genetic variants located in or near the $C F H, C F I, C 9$, $C 2 / C F B, C 3$ and VNT genes, encoding components of the complement system, are known to be associated with AMD [19]. Some of these genetic variants have been shown to affect complement activation levels, and could therefore also be used as biomarkers for complement system activity in AMD. We reviewed the reported associations between common AMD-associated variants and systemic complement system levels in Table 2. SNPs rs12144939 and rs1410996 in the $C F H$ gene have been associated with the $\mathrm{C} 3 \mathrm{~d} / \mathrm{C} 3$ ratio, and rs800292 has been associated with $\mathrm{Ba}$ and $\mathrm{C} 3 \mathrm{~d}$ levels and the $\mathrm{C} 3 \mathrm{~d} / \mathrm{C} 3$ ratio $[111,120,121]$. Genetic variants in the $C 2$ and $C F B$ genes have also been analyzed, and an association with complement activation fragments has been found for rs4151667 (with $\mathrm{C} 3 \mathrm{~d} / \mathrm{C} 3, \mathrm{Ba}$ and FB), rs641153 (with $\mathrm{C} 3 \mathrm{~d} / \mathrm{C} 3$ ), and rs9332739 (with Ba) $[111,113,120,121]$. SNP rs6795735 and rs2230199 in the $C 3$ gene seem to influence complement system activation as well. SNP rs6795735 associated with the C3d/C3 ratio, and rs2230199 with levels of $\mathrm{C} 3 \mathrm{~d}, \mathrm{C} 5 \mathrm{a}$, and the $\mathrm{C} 3 \mathrm{~d} /$ C3 ratio [109, 111, 120, 121]. The association of ARMS2 rs10490924 with complement activation is inconclusive. While one study reported the SNP to influence C5a levels [109], in another study, it did not [111], and a third study did not find an association with the $\mathrm{C} 3 \mathrm{~d} / \mathrm{C} 3$ ratio [120]. In a recent GWAS for complement activation levels, the AMDassociated variant that showed the strongest effect was rs6685931 located in the $C F H R 4$ gene. Previous associations described for $\mathrm{CFH}$ and $\mathrm{CFB} / \mathrm{C} 2$ were confirmed by the GWAS, while the associations of rs2230199 in $C 3$ and rs10490924 in ARMS2 could not be confirmed [122].

Recently, rare coding variants in the $C F H, C F I, C 3$ and $C 9$ genes have been described in AMD patients, and have also been shown to have an effect on systemic levels of complement components. Carriers of $\mathrm{CFH}$ Arg127His [123], Arg175Pro [124] and Cys192Phe [125] variants showed reduced FH levels. In carriers of CFI Gly119Arg [115], Gly188Ala [115] and Ala240Gly variants [126], reduced FI levels were observed. Carriers of the $C 9$ variant Arg95Ter showed C9 levels below the detection level [127], and in carriers of Pro167Ser [128], C9 levels were elevated. Other rare variants did not show an effect on systemic levels individually, but a functional effect on complement activation has been described. The effect of these rare variants has been recently reviewed by Geerlings and colleagues [129]. Rare coding variants, in particular those showing an effect on complement activation, may therefore also be useful to select patients for complementinhibiting treatments.

Besides genetic biomarkers, other biomarkers that associate with AMD and complement activity could also be used to identify AMD patients with an over-activated complement system. Other reported factors include low systemic triglyceride levels and high body mass index (BMI) [120].

\subsection{Gene- and Cell-Based Therapies}

The high and increasing prevalence of AMD together with the limited therapeutic options have boosted research for new therapies [12]. These new therapeutic strategies make use of the latest technological advances including gene therapy and stem cells. In this section, we review gene- and cell-based therapies that have been or are currently being tested in clinical trials. 
Table 2 AMD SNPs associated with systemic levels of complement components

\begin{tabular}{|c|c|c|c|c|c|c|}
\hline Gene & SNP & Study & $\begin{array}{l}\text { Allele/genotype } \\
\text { tested }\end{array}$ & $\begin{array}{l}\text { Complement activation } \\
\text { measurement(s) }\end{array}$ & $\begin{array}{l}\text { Direction of the } \\
\text { effect }\end{array}$ & $P$ value \\
\hline \multirow[t]{8}{*}{$\mathrm{CFH}$} & rs 12144939 & Ristau et al. [120] & $\mathrm{T}$ & $\mathrm{C} 3 \mathrm{~d} / \mathrm{C} 3$ & - & $4.6 \times 10^{-6}$ \\
\hline & \multirow[t]{2}{*}{ rs 1410996} & Ristau et al. [120] & $\mathrm{T}$ & $\mathrm{C} 3 \mathrm{~d} / \mathrm{C} 3$ & - & $10^{-4}$ \\
\hline & & Reynolds et al. [109] & TT, CT and TT & $\mathrm{Bb}, \mathrm{C} 3 \mathrm{a}, \mathrm{C} 5 \mathrm{a}, \mathrm{FH}$ & NA & \\
\hline & \multirow[t]{5}{*}{ rs 800292} & Hecker et al. [111] & $\mathrm{G}$ & $\mathrm{Ba}$ & + & $7.1 \times 10^{-6}$ \\
\hline & & Hecker et al. [111] & G & C3d & + & 0.0013 \\
\hline & & Ristau et al. [120] & A & $\mathrm{C} 3 \mathrm{~d} / \mathrm{C} 3$ & - & 0.003 \\
\hline & & Paun et al. [121] & A & $\mathrm{C} 3 \mathrm{~d} / \mathrm{C} 3$ & - & 0.002 \\
\hline & & Hecker et al. [111] & G & FB, FD, FH/FHR-1 & NA & \\
\hline CHFR4 & rs6685931 & $\begin{array}{l}\text { Lores-Motta et al. } \\
\text { [122] }\end{array}$ & $\mathrm{C}$ & $\mathrm{C} 3 \mathrm{~d} / \mathrm{C} 3$ & + & $6.32 \times 10^{-8}$ \\
\hline \multirow[t]{7}{*}{$C F B$} & \multirow[t]{5}{*}{ rs4151667 } & Hecker et al. [111] & $\mathrm{T}$ & $\mathrm{Ba}$ & + & $3.9 \times 10^{-6}$ \\
\hline & & Ristau et al. [120] & A & $\mathrm{C} 3 \mathrm{~d} / \mathrm{C} 3$ & - & $1.0 \times 10^{-5}$ \\
\hline & & Paun et al. [121] & A & $\mathrm{C} 3 \mathrm{~d} / \mathrm{C} 3$ & - & $4.1 \times 10^{-6}$ \\
\hline & & Hecker et al. [111] & $\mathrm{T}$ & FB, FD, FH/FHR-1, C5a, C3d & NA & \\
\hline & & $\begin{array}{l}\text { Smailhodzic et al. } \\
\text { [113] }\end{array}$ & TA & FB & - & $<0.001$ \\
\hline & \multirow[t]{2}{*}{ rs641153 } & Paun et al. [121] & A & $\mathrm{C} 3 \mathrm{~d} / \mathrm{C} 3$ & - & 0.048 \\
\hline & & Reynolds et al. [109] & $\mathrm{CT} / \mathrm{TT}$ & $\mathrm{Bb}, \mathrm{C} 3 \mathrm{a}, \mathrm{C} 5 \mathrm{a}, \mathrm{FH}$ & NA & \\
\hline \multirow[t]{3}{*}{$C 2$} & \multirow[t]{3}{*}{ rs9332739 } & Hecker et al. [111] & G & $\mathrm{Ba}$ & + & $2 \times 10^{-6}$ \\
\hline & & Hecker et al. [111] & G & FB, FD, FH/FHR-1, C5a, C3d & NA & \\
\hline & & Reynolds et al. [109] & $\mathrm{CG} / \mathrm{CC}$ & $\mathrm{Bb}, \mathrm{C} 3 \mathrm{a}, \mathrm{C} 5 \mathrm{a}, \mathrm{FH}$ & NA & \\
\hline \multirow[t]{7}{*}{$C 3$} & rs6795735 & Ristau et al. [120] & A & $\mathrm{C} 3 \mathrm{~d} / \mathrm{C} 3$ & + & 0.04 \\
\hline & \multirow[t]{6}{*}{ rs2230199 } & Reynolds et al. [109] & $\mathrm{CG} / \mathrm{GG}$ & $\mathrm{C5a}$ & + & 0.04 \\
\hline & & Ristau et al. [120] & G & $\mathrm{C} 3 \mathrm{~d} / \mathrm{C} 3$ & + & 0.04 \\
\hline & & Paun et al. [121] & G & $\mathrm{C} 3 \mathrm{~d} / \mathrm{C} 3$ & + & 0.035 \\
\hline & & Hecker et al. [111] & $\mathrm{C}$ & $\mathrm{C} 3 \mathrm{~d}$ & + & 0.039 \\
\hline & & Hecker et al. [111] & $\mathrm{C}$ & FB, FD, FH/FHR-1, C5a, Ba & NA & \\
\hline & & Reynolds et al. [109] & CG/GG & $\mathrm{Bb}, \mathrm{C} 3 \mathrm{a}, \mathrm{FH}$ & NA & \\
\hline \multirow[t]{3}{*}{ ARMS2 } & \multirow[t]{3}{*}{ rs10490924 } & Reynolds et al. [109] & GT/TT & C5a & + & 0.02 \\
\hline & & Reynolds et al. [109] & GT/TT & $\mathrm{Bb}, \mathrm{C} 3 \mathrm{a}, \mathrm{FH}$ & NA & \\
\hline & & Hecker et al. [111] & NS & FB, FD, FH/FHR-1, C5a, Ba, C3d & NA & \\
\hline
\end{tabular}

$A M D$ age-related macular degeneration, $N A$ not associated, $N S$ not specified, $S N P$ single-nucleotide polymorphism

\subsubsection{Gene Therapy}

Gene therapy introduces specific genetic material into the patient's cells, usually by means of a viral vector. The successful example of gene replacement therapy for the treatment of a monogenic retinal disease, Leber congenital amaurosis [130], motivated the development of gene therapy clinical trials for AMD. In AMD, the focus is on promoting the expression of a therapeutic protein in RPE cells. Viral vectors are delivered intravitreally or subretinally. An overview of gene therapy clinical trials for AMD is presented in Table 3 .

AAVCAGsCD59, discussed in Sect. 3.1, is the only gene therapy trial targeting the complement system which is currently being tested for GA, and inhibits MAC formation through CD59 expression. Other gene therapy trials target the neovascular form of AMD. AdGVPEDF.11D leads to expression of pigment epithelium-derived factor (PEDF), an anti-angiogenic protein that counteracts the effects of VEGF in the CNV process [131]. This therapy has not been further evaluated since the results of the phase I trial in 2006 [132]. AAV2-sFLT01 and rAAV.sFLT-1 both express soluble vascular endothelial growth factor receptor 1 (sFLT-1), an antagonist for VEGF [133]. The results of the phase I trial of AAV2-sFLT01 have recently been published with positive safety data and toleration of the drug after 3 years [134]. rAAV.sFLT-1 has already been evaluated in phase IIa; however, the control and the 


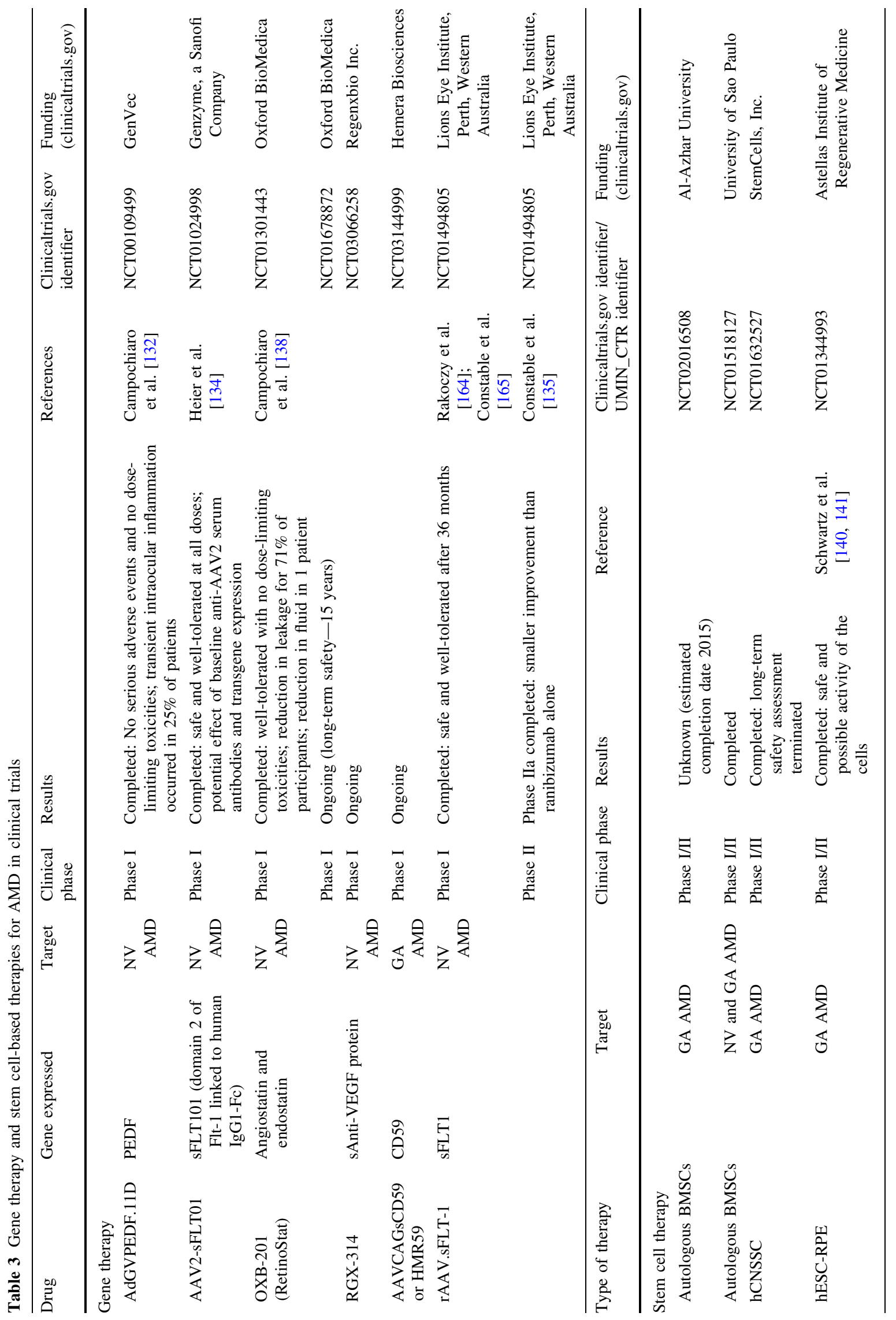




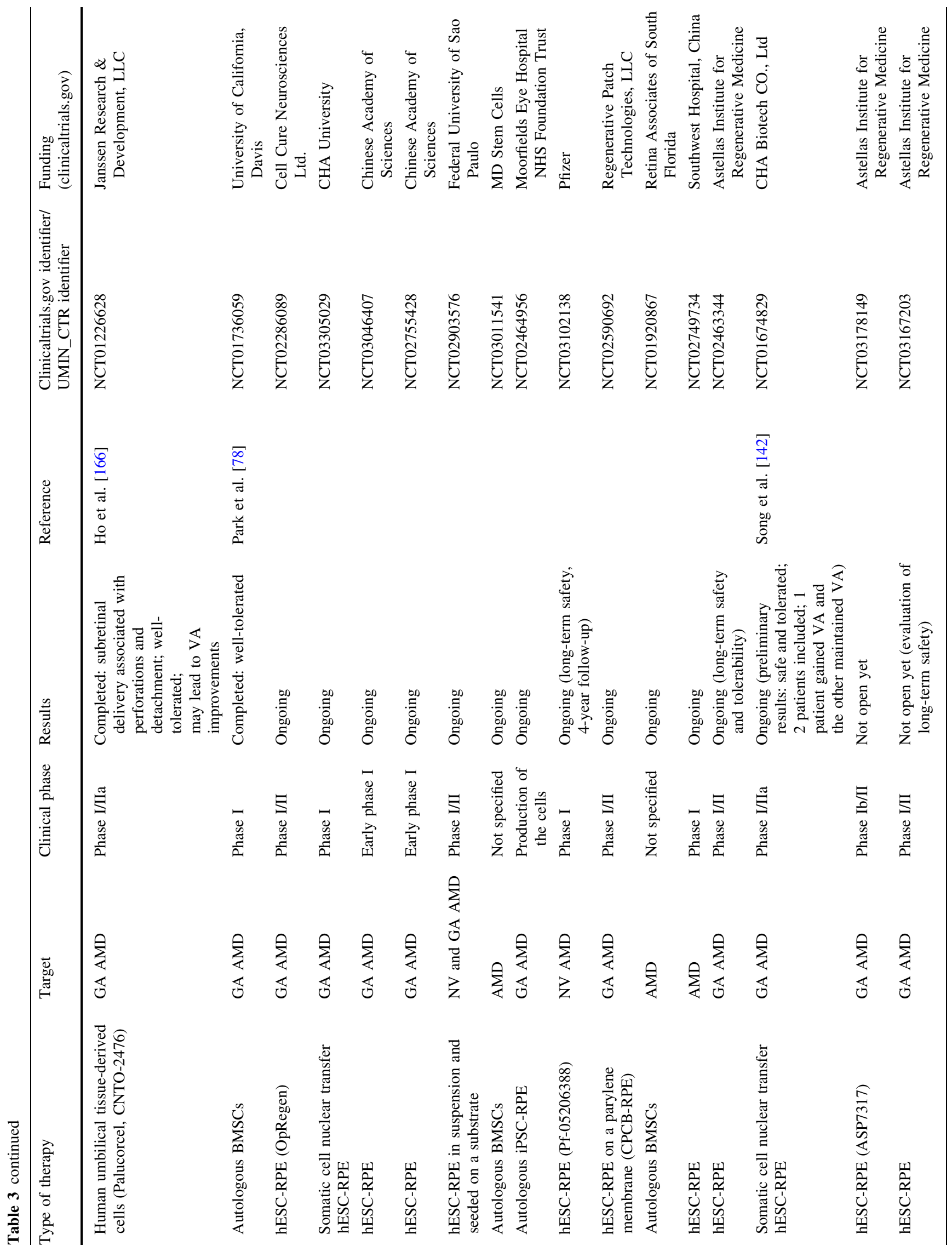




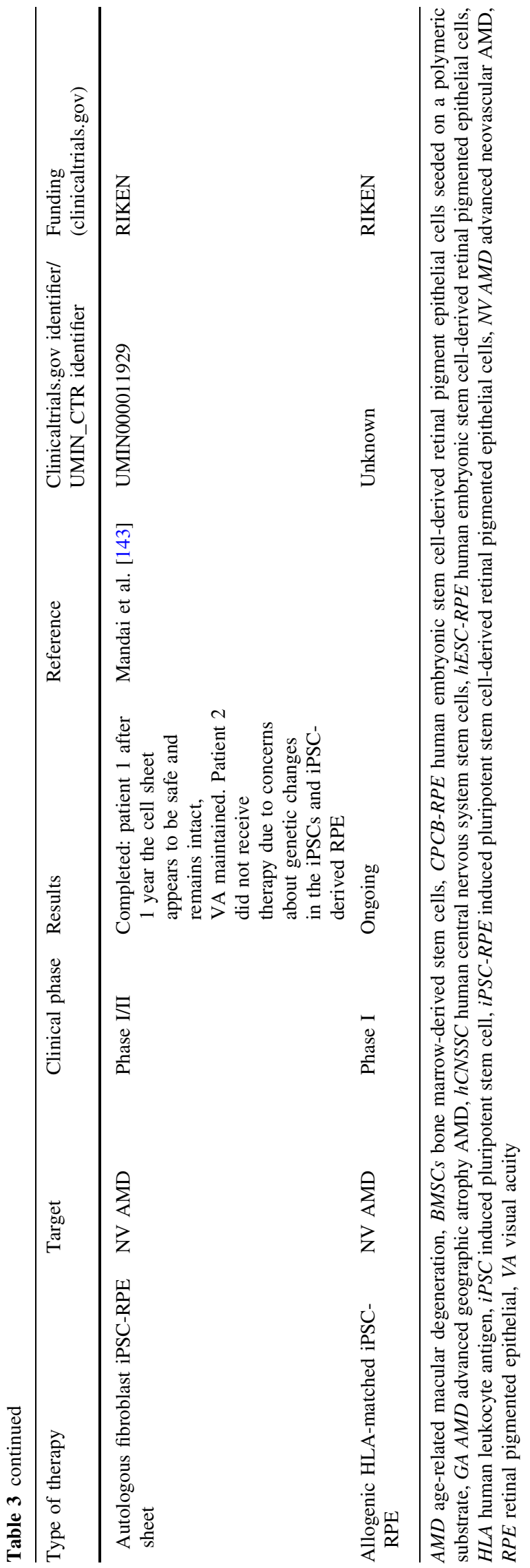

treatment groups performed worse than ranibizumab alone group [135]. OXB-201, also known as RetinoStat, leads to the expression of the anti-angiogenic proteolytic products angiostatin and endostatin [136, 137]. Phase I has already been completed, and no adverse events were observed [138]; therefore, long-term safety studies are ongoing. Finally, RGX-314 encodes for a soluble anti-VEGF protein and is currently being evaluated in phase I clinical trials.

Anti-angiogenic factors delivered using gene therapy might show also a variability in response as it has been described for the currently used anti-VEGF antibodies. Therefore, pharmacogenetic associations found for antiVEGF therapy might be analyzed in clinical trials of gene therapy for nvAMD.

In addition, research on gene therapy for supplementation of FH is currently ongoing [139], and supplementation therapy for FI might be useful, as carriers of rare variants show reduced FI levels. For this particular therapy, patient selection based on genotype will be required. Carriers of rare variants in $C F H$ and $C F I$ known to have strong effects on the protein function or levels would be the best candidates for inclusion in clinical trials.

\subsubsection{Stem Cell Therapy}

Another novel therapeutic approach with great potential for AMD is the use of stem cells, which are reprogrammed to the cell type of interest and transplanted to the patient. Transplantation of RPE cells derived from stem cells for AMD treatment is currently being evaluated in several clinical trials (Table 3). The first clinical trial started in 2011 and involved human embryonic stem cell (hESC)derived RPE cells (NCT01344993). The therapy was found to be safe with no tumorigenicity and showed potential effectiveness [140, 141]. These results have been followed up with a new improved therapy (NCT03178149, NCT03167203) that is currently being evaluated by developers in the Astellas Institute for Regenerative Medicine. Other ongoing clinical trials are also based on hESCderived RPE; however, their use requires immunosuppressive treatment, bearing risks [142] and raising ethical concerns due to the use of embryonic cells. More recently, the use of induced pluripotent stem cells (iPSC) has begun to be explored. One of the key benefits of this therapy is that immunosuppression is not needed, as the source is the patient's own somatic cells. However, it implies an increased cost of therapy, as it needs to be developed for each patient individually. The first clinical trial with iPSC (http://www.umin.ac.jp, UMIN000011929) has recently been performed at the Japanese research institute RIKEN, where a 70-year-old AMD patient received a transplant of a sheet of autologous iPSC-RPE. After 1 year of follow-up, no adverse events had been detected and the patient's 
vision remained stable [143]. However, this trial has been stopped for the second patient enrolled, because of genetic changes found in the generated iPSC [144]. This group has recently shifted their approach towards the use of allogenic human leukocyte antigen (HLA)-matched iPSC-RPE, and in March 2017, it was announced that the first patient received allogenic iPSC-RPE [145]. This approach would be less costly and would avoid the effect of the genetic AMD-risk variants that the patients carry. Nevertheless, it would most likely imply the use of immunosuppressant drugs. Contrary to these promising results of the group in RIKEN, in a back-to-back publication, it was reported that autologous adipose tissue-derived stem cells were administered bilaterally to three AMD patients in a stem cell clinic, leading to a severe visual loss in all cases [146]. These disastrous events highlight that even though stem cell therapy holds promise, strict regulations should be applied before any treatment with stem cells is administered to patients.

RPE stem cell therapy might be the best therapeutic option for advanced cases in which there is RPE degeneration; however, it involves the transplantation of new cells in a diseased environment, and as such, the survival of the new cells may depend on inflammation and oxidative stress levels in the host environment. The $\mathrm{C} 3 / \mathrm{C} 3$ ratio, as a marker of complement activation, malondialdehyde levels, as a marker of lipid peroxidation, and homocysteine levels, an oxidative stress marker, are molecular biomarkers for AMD that may correlate with the success of such therapies [147]. Moreover, autologous iPSC might not be the best option for AMD patients carrying highly penetrant genetic variants, and hESC or HLA-matched iPSC may be more effective in these patients.

\section{Discussion and Future Perspectives}

The use of genetic biomarkers to advise patients with AMD on the use of dietary supplements is a topic of intense debate that has not yet been settled. Based on the recent findings of Assel at al. [35], dietary supplementation for slowing down disease progression should be prescribed to any AMD patient, irrespective of $C F H$ and ARMS2 genotypes, but this is contradicted by a more recent study by Vavvas et al. on an extended dataset, which concluded that the use of the AREDS formulation should be based on patient-specific genotypes [36]. However, the findings in all studies of this debate are based on the AREDS dataset only, and future independent prospective studies would be beneficial to draw a definite conclusion, as well as to further investigate if other genetic variants may interact with the formulation.
In regard to the pharmacogenetics of anti-VEGF treatment, results are not conclusive yet; therefore, these results are not yet helpful for precision medicine. Nonetheless, recurrent results from multiple studies suggest that SNP rs1061170 in $C F H$ may influence response to treatment. This finding could potentially be explained by the effect of this SNP on faster disease progression [148]. However, this association was not detected in the analyses from the CATT and IVAN clinical trials [71, 72], therefore warranting further investigation. Additionally, the magnitude of the effect of this variant might not reach clinical utility and would need to be combined with other genetic variants or clinical parameters. Other compelling candidate genetic variants for further evaluation include ARMS2 rs10490924, VEGFA rs833061, OR52B4 rs4910623, NRP1 rs2070296, APOE $\varepsilon 4$ allele, IL8 rs4073 and PEDF rs1136287. OR52B4 rs4910623 was identified in a GWAS using pooled DNA, indicating that a GWAS with single-patient genotyping and increased statistical power may reveal new associated variants. Additionally, rare variants potentially bearing larger effects, and therefore clinical relevance, have not been evaluated yet [149].

A key problem remains that the definition of response is not consistently defined across cohorts. In 2015, in order to provide a consensus, a committee of retinal specialists proposed definitions of good, poor and non-response based on a combination of anatomical and functional measurements [150]. These definitions should be adopted by researchers in future studies, which would enable study comparisons in a standardized framework. Analysis of the different outcome measures used for these definitions as continuous variables would be also highly valuable. Additionally, prospective studies with sufficient statistical power would allow sub-phenotype analyses, which may reveal new or stronger associations.

Biomarkers identified in aqueous humor samples are VEGF and IL-6; however, these samples are not taken routinely. IL-6, IL-17, TNF- $\alpha$ and C3a have been identified as potential systemic biomarkers, and therefore could be readily measured before treatment. Moreover, as baseline VEGF has been associated with response in aqueous humor samples, it could be further investigated as a systemic biomarker. Recent studies suggest that anti-VEGF treatment may lead to an increased risk of GA development [151]. Therefore, screening of genetic markers together with other biomarkers and clinical parameters for effective anti-VEGF therapy planning may become necessary. Clinical trials would be albeit needed before the screening of these biomarkers can be implemented in the clinic.

Complement therapies are being developed for the treatment of GA, and biomarkers for complement activity could be useful to identify the most suitable AMD patients for these therapies. Systemic levels of complement 
activation fragments such as the $\mathrm{C} 3 \mathrm{~d} / \mathrm{C} 3$ ratio can be used as biomarkers for complement activity in AMD. Moreover, levels of the specific target of each drug could be a useful biomarker. Therapies undergoing trials are targeting FD, $\mathrm{C} 3$, properdin and $\mathrm{C} 5$. FD levels have been seen to be higher in AMD patients compared to controls, and therefore, they could be a useful biomarker for this specific therapy. C3 levels do not differ between AMD and controls, and properdin and C5 levels have not been evaluated. A comprehensive analysis of the complement system components in AMD could identify new potential biomarkers. However, how systemic measurements reflect the local situation at the disease site needs to be further investigated.

Additionally, AMD-associated SNPs that associate with systemic complement activation can be used as robust biomarkers. The added value of these genetic biomarkers is that as they are associated with disease risk, they most probably reflect complement activity in the eye, whereas the overall systemic complement activation may not always be representative of the conditions at the disease site. rs12144939, rs1410996 and rs800292 in $C F H$, rs4151667, rs641153 and rs9332739 in $C 2 / C F B$, and rs6795735 and rs2230199 in $C 3$ have been reported to be associated with systemic complement activation levels. In a recent GWAS for complement activation levels, the AMD-associated variant that showed the strongest effect was rs6685931 located in the CFHR4 gene. Moreover, rare variants in the $C F H$ gene (Arg127His, Arg175Pro and Cys192Phe), in the CFI gene (Gly119Arg, Gly188Ala and Ala240Gly) and in the $C 9$ gene (Arg95Ter and Pro167Ser) have been associated with altered FH, FI and C9 levels, respectively. However, the magnitude of the effects of these genetic variants at the disease site still needs to be evaluated. Additionally, other variants for which a systemic effect has not been detected most probably have a local effect. Consequently, genetic studies using aqueous humor samples are greatly needed. The identified genetic factors may be used alongside systemic complement activation levels and other environmental factors such as BMI and triglyceride levels to identify AMD patients with a burden of the complement system in their AMD disease. Well-powered replication studies are needed, as well as comprehensive genetic studies of the effect of all the 52 independently AMD-associated variants on systemic complement activation levels [19].

Other new therapeutic approaches will most probably not work in the same manner for all AMD patients. As a consequence, a deeper molecular characterization of AMD patients including proteomics, metabolomics, transcriptomics and genomics is essential. Such in-depth characterization will help to understand the molecular drivers in each individual patient and to develop pharmacomics, paving the way towards precision medicine in AMD.

\section{Compliance with Ethical Standards}

Funding The research leading to these results has received funding from the European Research Council under the European Union's Seventh Framework Programme (FP/2007-2013)/ERC Grant Agreement n. 310644 (MACULA). The research leading to these results has received funding from the European Research Council under the European Union's Horizon 2020 Research and Innovation Programme/ERC Grant Agreement n. 737607 (MACULA2). This project has received funding from the European Union's Seventh Framework Programme for research, technological development and demonstration under Grant agreement no. 317472 (EyeTN).

Conflict of interest The authors LLM and EKdJ declare no conflicts of interest. AIdH declares the following conflicts of interest: consultancy for Ionis Pharmaceuticals, Inc.

Open Access This article is distributed under the terms of the Creative Commons Attribution-NonCommercial 4.0 International License (http://creativecommons.org/licenses/by-nc/4.0/), which permits any noncommercial use, distribution, and reproduction in any medium, provided you give appropriate credit to the original author(s) and the source, provide a link to the Creative Commons license, and indicate if changes were made.

\section{References}

1. Weinshilboum RM, Wang L. Pharmacogenomics: precision medicine and drug response. Mayo Clin Proc. 2017;92:1711-22.

2. Thompson MA, Godden JJ, Weissman SM, Wham D, Wilson A, Ruggeri A, Mullane MP, Weese JL. Implementing an oncology precision medicine clinic in a large community health system. Am J Manag Care. 2017;23:Sp425-427.

3. Arnall JR, Petro R, Patel JN, Kennedy L. A clinical pharmacy pilot within a Precision Medicine Program for cancer patients and review of related pharmacist clinical practice. J Oncol Pharm Pract. 2017. https://doi.org/10.1177/1078155217738324.

4. Anonymous Pharmgkb dosing guidelines. https://www. pharmgkb.org/guidelines.

5. Henricks LM, Opdam FL, Beijnen JH, Cats A, Schellens JHM. DPYD genotype-guided dose individualization to improve patient safety of fluoropyrimidine therapy: call for a drug label update. Ann Oncol. 2017;28(12):2915-22. https://doi.org/10. 1093/annonc/mdx411.

6. Pirmohamed M, Burnside G, Eriksson N, Jorgensen AL, Toh CH, Nicholson T, Kesteven P, Christersson C, Wahlstrom B, Stafberg C, Zhang JE, Leathart JB, Kohnke H, Maitland-van der Zee AH, Williamson PR, Daly AK, Avery P, Kamali F, Wadelius M. A randomized trial of genotype-guided dosing of warfarin. N Engl J Med. 2013;369:2294-303.

7. Gage BF, Bass AR, Lin H, Woller SC, Stevens SM, Al-Hammadi $\mathrm{N}$, Li J, Rodriguez $\mathrm{T} \mathrm{Jr}$, Miller JP, McMillin GA, Pendleton RC, Jaffer AK, King CR, Whipple BD, Porche-Sorbet R, Napoli L, Merritt K, Thompson AM, Hyun G, Anderson JL, Hollomon W, Barrack RL, Nunley RM, Moskowitz G, DavilaRoman V, Eby CS. Effect of genotype-guided warfarin dosing on clinical events and anticoagulation control among patients undergoing hip or knee arthroplasty: the GIFT randomized clinical trial. JAMA. 2017;318:1115-24. 
8. Verhoef TI, Redekop WK, Langenskiold S, Kamali F, Wadelius M, Burnside G, Maitland-van der Zee AH, Hughes DA, Pirmohamed M. Cost-effectiveness of pharmacogenetic-guided dosing of warfarin in the United Kingdom and Sweden. Pharmacogenomics J. 2016;16:478-84.

9. Jacob M, Lopata AL, Dasouki M, Abdel Rahman AM. Metabolomics toward personalized medicine. Mass Spectrom Rev. 2017. https://doi.org/10.1002/mas.21548.

10. Klaver CC, Wolfs RC, Vingerling JR, Hofman A, de Jong PT. Age-specific prevalence and causes of blindness and visual impairment in an older population: the Rotterdam Study. Arch Ophthalmol. 1998;116:653-8.

11. Flaxman SR, Bourne RRA, Resnikoff S, Ackland P, Braithwaite T, Cicinelli MV, Das A, Jonas JB, Keeffe J, Kempen JH, Leasher J, Limburg H, Naidoo K, Pesudovs K, Silvester A, Stevens GA, Tahhan N, Wong TY, Taylor HR. Global causes of blindness and distance vision impairment 1990-2020: a systematic review and meta-analysis. Lancet Glob Health. 2017;5(12):e1221-34. https://doi.org/10.1016/S2214-109X(17)3 0393-5.

12. Wong WL, Su X, Li X, Cheung CM, Klein R, Cheng CY, Wong TY. Global prevalence of age-related macular degeneration and disease burden projection for 2020 and 2040: a systematic review and meta-analysis. Lancet Glob Health. 2014;2:e106-16.

13. Garcia-Layana A, Cabrera-Lopez F, Garcia-Arumi J, AriasBarquet L, Ruiz-Moreno JM. Early and intermediate age-related macular degeneration: update and clinical review. Clin Interv Aging. 2017;12:1579-87.

14. Holz FG, Strauss EC, Schmitz-Valckenberg S, van Lookeren Campagne M. Geographic atrophy: clinical features and potential therapeutic approaches. Ophthalmology. 2014;121:1079-91.

15. Ferris FL 3rd, Fine SL, Hyman L. Age-related macular degeneration and blindness due to neovascular maculopathy. Arch Ophthalmol. 1984;102:1640-2.

16. Seddon JM, Cote J, Page WF, Aggen SH, Neale MC. The US twin study of age-related macular degeneration: relative roles of genetic and environmental influences. Arch Ophthalmol. 2005; 123:321-7.

17. Klein RJ, Zeiss C, Chew EY, Tsai JY, Sackler RS, Haynes C, Henning AK, SanGiovanni JP, Mane SM, Mayne ST, Bracken MB, Ferris FL, Ott J, Barnstable C, Hoh J. Complement factor H polymorphism in age-related macular degeneration. Science. 2005;308:385-9.

18. Rivera A, Fisher SA, Fritsche LG, Keilhauer CN, Lichtner P, Meitinger T, Weber BH. Hypothetical LOC387715 is a second major susceptibility gene for age-related macular degeneration, contributing independently of complement factor $\mathrm{H}$ to disease risk. Hum Mol Genet. 2005;14:3227-36.

19. Fritsche LG, Igl W, Bailey JN, Grassmann F, Sengupta S, Bragg-Gresham JL, Burdon KP, Hebbring SJ, Wen C, Gorski M, Kim IK, Cho D, Zack D, Souied E, Scholl HP, Bala E, Lee KE, Hunter DJ, Sardell RJ, Mitchell P, Merriam JE, Cipriani V, Hoffman JD, Schick T, Lechanteur YT, Guymer RH, Johnson MP, Jiang Y, Stanton CM, Buitendijk GH, Zhan X, Kwong AM, Boleda A, Brooks M, Gieser L, Ratnapriya R, Branham KE, Foerster JR, Heckenlively JR, Othman MI, Vote BJ, Liang HH, Souzeau E, McAllister IL, Isaacs T, Hall J, Lake S, Mackey DA, Constable IJ, Craig JE, Kitchner TE, Yang Z, Su Z, Luo H, Chen D, Ouyang H, Flagg K, Lin D, Mao G, Ferreyra H, Stark K, von Strachwitz CN, Wolf A, Brandl C, Rudolph G, Olden M, Morrison MA, Morgan DJ, Schu M, Ahn J, Silvestri G, Tsironi EE, Park KH, Farrer LA, Orlin A, Brucker A, Li M, Curcio CA, Mohand-Said S, Sahel JA, Audo I, Benchaboune M, Cree AJ, Rennie CA, Goverdhan SV, Grunin M, Hagbi-Levi S, Campochiaro P, Katsanis N, Holz FG, Blond F, Blanche H, Deleuze JF, Igo RP Jr, Truitt B, Peachey NS, Meuer SM, Myers CE,
Moore EL, Klein R, Hauser MA, Postel EA, Courtenay MD, Schwartz SG, Kovach JL, Scott WK, Liew G, Tan AG, Gopinath B, Merriam JC, Smith RT, Khan JC, Shahid H, Moore AT, McGrath JA, Laux R, Brantley MA Jr, Agarwal A, Ersoy L, Caramoy A, Langmann T, Saksens NT, de Jong EK, Hoyng CB, Cain MS, Richardson AJ, Martin TM, Blangero J, Weeks DE, Dhillon B, van Duijn CM, Doheny KF, Romm J, Klaver CC, Hayward C, Gorin MB, Klein ML, Baird PN, den Hollander AI, Fauser S, Yates JR, Allikmets R, Wang JJ, Schaumberg DA, Klein BE, Hagstrom SA, Chowers I, Lotery AJ, Leveillard T, Zhang K, Brilliant MH, Hewitt AW, Swaroop A, Chew EY, Pericak-Vance MA, DeAngelis M, Stambolian D, Haines JL, Iyengar SK, Weber BH, Abecasis GR, Heid IM. A large genome-wide association study of age-related macular degeneration highlights contributions of rare and common variants. Nat Genet. 2016;48:134-43.

20. Chakravarthy U, Wong TY, Fletcher A, Piault E, Evans C, Zlateva G, Buggage R, Pleil A, Mitchell P. Clinical risk factors for age-related macular degeneration: a systematic review and meta-analysis. BMC Ophthalmol. 2010;10:31.

21. Betteridge DJ. What is oxidative stress? Metabolism. 2000;49:3-8.

22. Beatty S, Koh H, Phil M, Henson D, Boulton M. The role of oxidative stress in the pathogenesis of age-related macular degeneration. Surv Ophthalmol. 2000;45:115-34.

23. Anonymous. A randomized, placebo-controlled, clinical trial of high-dose supplementation with vitamins $\mathrm{C}$ and $\mathrm{E}$, beta carotene, and zinc for age-related macular degeneration and vision loss: AREDS report no. 8. Arch Ophthalmol. 2001;119: 1417-36.

24. Anonymous. Lutein + zeaxanthin and omega- 3 fatty acids for age-related macular degeneration: the Age-Related Eye Disease Study 2 (AREDS2) randomized clinical trial. Jama. 2013;309: 2005-15.

25. Seddon JM, Silver RE, Kwong M, Rosner B. Risk prediction for progression of macular degeneration: 10 common and rare genetic variants, demographic, environmental, and macular covariates. Invest Ophthalmol Vis Sci. 2015;56:2192-202.

26. Klein ML, Francis PJ, Rosner B, Reynolds R, Hamon SC, Schultz DW, Ott J, Seddon JM. CFH and LOC387715/ARMS2 genotypes and treatment with antioxidants and zinc for agerelated macular degeneration. Ophthalmology. 2008;115: 1019-25.

27. Awh CC, Lane AM, Hawken S, Zanke B, Kim IK. CFH and ARMS2 genetic polymorphisms predict response to antioxidants and zinc in patients with age-related macular degeneration. Ophthalmology. 2013;120:2317-23.

28. Chew EY, Klein ML, Clemons TE, Agron E, Ratnapriya R, Edwards AO, Fritsche LG, Swaroop A, Abecasis GR. No clinically significant association between CFH and ARMS2 genotypes and response to nutritional supplements: AREDS report number 38. Ophthalmology. 2014;121:2173-80.

29. Awh CC, Hawken S, Zanke BW. Treatment response to antioxidants and zinc based on CFH and ARMS2 genetic risk allele number in the Age-Related Eye Disease Study. Ophthalmology. 2015;122:162-9.

30. Chew EY, Klein ML, Clemons TE, Agron E, Abecasis GR. Genetic testing in persons with age-related macular degeneration and the use of the AREDS supplements: to test or not to test? Ophthalmology. 2015;122:212-5.

31. Seddon JM, Silver RE, Rosner B. Response to AREDS supplements according to genetic factors: survival analysis approach using the eye as the unit of analysis. Br J Ophthalmol. 2016;100:1731-7.

32. Awh CC, Zanke B. Re: Chew et al.: genetic testing in persons with age-related macular degeneration and the use of AREDS 
supplements: to test or not to test? (Ophthalmology 2015;122:212-5). Ophthalmology. 2015;122:e62-3.

33. Odaibo SG. Re: Awh et al.: treatment response to antioxidants and zinc based on CFH and ARMS2 genetic risk allele number in the Age-Related Eye Disease Study (Ophthalmology 2015;122:162-9). Ophthalmology. 2015;122:e58.

34. Pearlman J. Re: Chew et al.: genetic testing in persons with agerelated macular degeneration and the use of the AREDS supplements: to test or not to test? (Ophthalmology 2015;122:212-5). Ophthalmology. 2015;122:e60-1.

35. Assel MJ, Li F, Wang Y, Allen AS, Baggerly KA, Vickers AJ. Genetic polymorphisms of CFH and ARMS2 do not predict response to antioxidants and zinc in patients with age-related macular degeneration: independent statistical evaluations of data from the Age-Related Eye Disease Study. Ophthalmology. 2018;125(3):391-7. https://doi.org/10.1016/j.ophtha.2017.09. 008.

36. Vavvas DG, Small KW, Awh CC, Zanke BW, Tibshirani RJ, Kustra R. CFH and ARMS2 genetic risk determines progression to neovascular age-related macular degeneration after antioxidant and zinc supplementation. Proc Natl Acad Sci USA. 2018;115:E696-704.

37. Leung DW, Cachianes G, Kuang WJ, Goeddel DV, Ferrara N. Vascular endothelial growth factor is a secreted angiogenic mitogen. Science. 1989;246:1306-9.

38. Shibuya M. Vascular endothelial growth factor and its receptor system: physiological functions in angiogenesis and pathological roles in various diseases. J Biochem. 2013;153:13-9.

39. McLeod DS, Grebe R, Bhutto I, Merges C, Baba T, Lutty GA. Relationship between RPE and choriocapillaris in age-related macular degeneration. Invest Ophthalmol Vis Sci. 2009;50:4982-91.

40. Pons M, Marin-Castano ME. Cigarette smoke-related hydroquinone dysregulates MCP-1, VEGF and PEDF expression in retinal pigment epithelium in vitro and in vivo. PLoS One. 2011;6:e16722.

41. Nozaki M, Raisler BJ, Sakurai E, Sarma JV, Barnum SR, Lambris JD, Chen Y, Zhang K, Ambati BK, Baffi JZ, Ambati J. Drusen complement components $\mathrm{C} 3 \mathrm{a}$ and $\mathrm{C} 5 \mathrm{a}$ promote choroidal neovascularization. Proc Natl Acad Sci USA. 2006;103:2328-33.

42. Martin DF, Maguire MG, Ying GS, Grunwald JE, Fine SL, Jaffe GJ. Ranibizumab and bevacizumab for neovascular age-related macular degeneration. N Engl J Med. 2011;364:1897-908.

43. Martin DF, Maguire MG, Fine SL, Ying GS, Jaffe GJ, Grunwald JE, Toth C, Redford M, Ferris FL 3rd. Ranibizumab and bevacizumab for treatment of neovascular age-related macular degeneration: two-year results. Ophthalmology. 2012;119:1388-98.

44. Chakravarthy U, Harding SP, Rogers CA, Downes SM, Lotery AJ, Wordsworth S, Reeves BC. Ranibizumab versus bevacizumab to treat neovascular age-related macular degeneration: one-year findings from the IVAN randomized trial. Ophthalmology. 2012;119:1399-411.

45. Chakravarthy U, Harding SP, Rogers CA, Downes SM, Lotery AJ, Culliford LA, Reeves BC. Alternative treatments to inhibit VEGF in age-related choroidal neovascularisation: 2-year findings of the IVAN randomised controlled trial. Lancet. 2013;382:1258-67.

46. Rosenfeld PJ, Brown DM, Heier JS, Boyer DS, Kaiser PK, Chung CY, Kim RY, Group MS. Ranibizumab for neovascular age-related macular degeneration. New England Journal of Medicine. 2006;355:1419-31.

47. Brown DM, Michels M, Kaiser PK, Heier JS, Sy JP, Ianchulev T, Group AS. Ranibizumab versus verteporfin photodynamic therapy for neovascular age-related macular degeneration: two- year results of the ANCHOR study. Ophthalmology. 2009;116(57-65):e55.

48. Tsilimbaris MK, Lopez-Galvez MI, Gallego-Pinazo R, Margaron P, Lambrou GN. Epidemiological and clinical baseline characteristics as predictive biomarkers of response to antiVEGF treatment in patients with neovascular AMD. J Ophthalmol. 2016;2016:4367631.

49. van Asten F, Rovers MM, Lechanteur YT, Smailhodzic D, Muether PS, Chen J, den Hollander AI, Fauser S, Hoyng CB, van der Wilt GJ, Klevering BJ. Predicting non-response to ranibizumab in patients with neovascular age-related macular degeneration. Ophthalmic Epidemiol. 2014;21:347-55.

50. Brantley MA Jr, Fang AM, King JM, Tewari A, Kymes SM, Shiels A. Association of complement factor $\mathrm{H}$ and LOC387715 genotypes with response of exudative age-related macular degeneration to intravitreal bevacizumab. Ophthalmology. 2007;114:2168-73.

51. Lee AY, Raya AK, Kymes SM, Shiels A, Brantley MA Jr. Pharmacogenetics of complement factor $\mathrm{H}(\mathrm{Y} 402 \mathrm{H})$ and treatment of exudative age-related macular degeneration with ranibizumab. Br J Ophthalmol. 2009;93:610-3.

52. Imai D, Mori K, Horie-Inoue K, Gehlbach PL, Awata T, Inoue $\mathrm{S}$, Yoneya S. CFH, VEGF, and PEDF genotypes and the response to intravitreous injection of bevacizumab for the treatment of age-related macular degeneration. J Ocul Biol Dis Infor. 2010;3:53-9.

53. Nischler C, Oberkofler H, Ortner C, Paikl D, Riha W, Lang N, Patsch W, Egger SF. Complement factor H Y402H gene polymorphism and response to intravitreal bevacizumab in exudative age-related macular degeneration. Acta Ophthalmol. 2011;89:e344-9.

54. Kloeckener-Gruissem B, Barthelmes D, Labs S, Schindler C, Kurz-Levin M, Michels S, Fleischhauer J, Berger W, Sutter F, Menghini M. Genetic association with response to intravitreal ranibizumab in patients with neovascular AMD. Invest Ophthalmol Vis Sci. 2011;52:4694-702.

55. Smailhodzic D, Muether PS, Chen J, Kwestro A, Zhang AY, Omar A, Van de Ven JP, Keunen JE, Kirchhof B, Hoyng CB, Klevering BJ, Koenekoop RK, Fauser S, den Hollander AI. Cumulative effect of risk alleles in CFH, ARMS2, and VEGFA on the response to ranibizumab treatment in age-related macular degeneration. Ophthalmology. 2012;119:2304-11.

56. Menghini M, Kloeckener-Gruissem B, Fleischhauer J, KurzLevin MM, Sutter FK, Berger W, Barthelmes D. Impact of loading phase, initial response and $\mathrm{CFH}$ genotype on the longterm outcome of treatment for neovascular age-related macular degeneration. PLoS One. 2012;7:e42014.

57. Kang HK, Yoon MH, Lee DH, Chin HS. Pharmacogenetic influence of LOC387715/HTRA1 on the efficacy of bevacizumab treatment for age-related macular degeneration in a Korean population. Korean J Ophthalmol. 2012;26:414-22.

58. Dikmetas O, Kadayifcilar S, Eldem B. The effect of $\mathrm{CFH}$ polymorphisms on the response to the treatment of age-related macular degeneration (AMD) with intravitreal ranibizumab. Mol Vis. 2013;19:2571-8.

59. Hautamaki A, Kivioja J, Seitsonen S, Savolainen ER, Liinamaa MJ, Luoma A, Jarvela I, Immonen I. The IL-8, VEGF, and CFH polymorphisms and bevacizumab in age-related macular degeneration. Ophthalmology. 2014;121(973-973):e971.

60. Piermarocchi S, Miotto S, Colavito D, Leon A, Segato T. Combined effects of genetic and non-genetic risk factors affect response to ranibizumab in exudative age-related macular degeneration. Acta Ophthalmol. 2015;93:e451-7.

61. Medina FM, Alves Lopes da Motta A, Takahashi WY, Carricondo PC, Dos Santos Motta MM, Melo MB, Vasconcellos JP. Pharmacogenetic effect of complement factor $\mathrm{H}$ gene 
polymorphism in response to the initial intravitreal injection of bevacizumab for wet age-related macular degeneration. Ophthalmic Res. 2015;54:169-74.

62. Shah AR, Williams S, Baumal CR, Rosner B, Duker JS, Seddon JM. Predictors of response to intravitreal anti-vascular endothelial growth factor treatment of age-related macular degeneration. Am J Ophthalmol. 2016;163(154-166):e158.

63. Medina FMC, Motta A, Takahashi WY, Carricondo PC, Motta $\mathrm{M}$, Melo MB, Vasconcellos JPC. Association of the CFH $\mathrm{Y} 402 \mathrm{H}$ polymorphism with the 1-year response of exudative AMD to intravitreal anti-VEGF treatment in the Brazilian population. Ophthalmic Res. 2017. https://doi.org/10.1159/ 000475995 .

64. Teper SJ, Nowinska A, Pilat J, Palucha A, Wylegala E. Involvement of genetic factors in the response to a variabledosing ranibizumab treatment regimen for age-related macular degeneration. Mol Vis. 2010;16:2598-604.

65. McKibbin M, Ali M, Bansal S, Baxter PD, West K, Williams G, Cassidy $\mathrm{F}$, Inglehearn $\mathrm{CF}$. CFH, VEGF and HTRA1 promoter genotype may influence the response to intravitreal ranibizumab therapy for neovascular age-related macular degeneration. Br J Ophthalmol. 2012;96:208-12.

66. Orlin A, Hadley D, Chang W, Ho AC, Brown G, Kaiser RS, Regillo CD, Godshalk AN, Lier A, Kaderli B, Stambolian D. Association between high-risk disease loci and response to antivascular endothelial growth factor treatment for wet age-related macular degeneration. Retina. 2012;32:4-9.

67. Tian J, Qin X, Fang K, Chen Q, Hou J, Li J, Yu W, Chen D, Hu $\mathrm{Y}, \mathrm{Li}$ X. Association of genetic polymorphisms with response to bevacizumab for neovascular age-related macular degeneration in the Chinese population. Pharmacogenomics. 2012;13:779-87.

68. Chang W, Noh DH, Sagong M, Kim IT. Pharmacogenetic association with early response to intravitreal ranibizumab for age-related macular degeneration in a Korean population. Mol Vis. 2013;19:702-9.

69. Kitchens JW, Kassem N, Wood W, Stone TW, Isernhagen R, Wood E, Hancock BA, Radovich M, Waymire J, Li L, Schneider BP. A pharmacogenetics study to predict outcome in patients receiving anti-VEGF therapy in age related macular degeneration. Clin Ophthalmol. 2013;7:1987-93.

70. Abedi F, Wickremasinghe S, Richardson AJ, Islam AF, Guymer RH, Baird PN. Genetic influences on the outcome of anti-vascular endothelial growth factor treatment in neovascular agerelated macular degeneration. Ophthalmology. 2013;120: 1641-8.

71. Hagstrom SA, Ying GS, Pauer GJ, Sturgill-Short GM, Huang J, Callanan DG, Kim IK, Klein ML, Maguire MG, Martin DF. Pharmacogenetics for genes associated with age-related macular degeneration in the Comparison of AMD Treatments Trials (CATT). Ophthalmology. 2013;120:593-9.

72. Lotery AJ, Gibson J, Cree AJ, Downes SM, Harding SP, Rogers CA, Reeves BC, Ennis S, Chakravarthy U. Alternative Treatments to Inhibit VEGF in Patients with Age-Related Choroidal Neovascularisation (IVAN) Study Group. Pharmacogenetic associations with vascular endothelial growth factor inhibition in participants with neovascular age-related macular degeneration in the IVAN study. Ophthalmology. 2013;120:2637-43.

73. Hautamaki A, Kivioja J, Vavuli S, Kakko S, Savolainen ER, Savolainen MJ, Liinamaa MJ, Seitsonen S, Onkamo P, Jarvela I, Immonen I. Interleukin 8 promoter polymorphism predicts the initial response to bevacizumab treatment for exudative agerelated macular degeneration. Retina (Philadelphia, Pa.). 2013;33:1815-27.

74. Habibi I, Sfar I, Kort F, Aounallah-Skhiri H, Chebil A, Chouchene I, Bouraoui R, Limaiem R, Largheche L, JendoubiAyed S, Makhlouf M, Ben Abdallah T, Ayed K, El Matri L,
Gorgi Y. Y402H polymorphism in complement factor $\mathrm{H}$ and age-related macular degeneration in the Tunisian population. Ophthalmic Res. 2013;49:177-84.

75. Yuan D, Yuan D, Liu X, Yuan S, Xie P, Liu Q. Genetic association with response to intravitreal ranibizumab for neovascular age-related macular degeneration in the Han Chinese population. Ophthalmologica. 2013;230:227-32.

76. Habibi I, Kort F, Sfar I, Chebil A, Bouraoui R, Ben Abdallah T, Gorgi Y, El Matri L. Effect of risk alleles in $\mathrm{CFH}, \mathrm{C} 3$, and VEGFA on the response to intravitreal bevacizumab in Tunisian patients with neovascular age-related macular degeneration. Klin Monbl Augenheilkd. 2016;233:465-70.

77. Valverde-Megías A, Veganzones-de-Castro S, Donate-Lopez J, Maestro-de-Las-Casas ML, Megias-Fresno A, Garcia-Feijoo J. ARMS2 A69S polymorphism is associated with the number of ranibizumab injections needed for exudative age-related macular degeneration in a pro re nata regimen during 4 years of follow-up. Graefes Arch Clin Exp Ophthalmol. 2017;255(11): 2091-8. https://doi.org/10.1007/s00417-017-3748-0.

78. Park UC, Shin JY, Kim SJ, Shin ES, Lee JE, McCarthy LC, Newcombe PJ, Xu CF, Chung H, Yu HG. Genetic factors associated with response to intravitreal ranibizumab in Korean patients with neovascular age-related macular degeneration. Retina. 2014;34:288-97.

79. Chen H, Yu KD, Xu GZ. Association between variant $\mathrm{Y} 402 \mathrm{H}$ in age-related macular degeneration (AMD) susceptibility gene $\mathrm{CFH}$ and treatment response of AMD: a meta-analysis. PLoS One. 2012;7:e42464.

80. Chen G, Tzekov R, Li W, Jiang F, Mao S, Tong Y. Pharmacogenetics of complement factor $\mathrm{H}$ Y $402 \mathrm{H}$ polymorphism and treatment of neovascular AMD with anti-VEGF agents: a metaanalysis. Sci Rep. 2015;5:14517.

81. Hong N, Shen Y, Yu CY, Wang SQ, Tong JP. Association of the polymorphism $\mathrm{Y} 402 \mathrm{H}$ in the $\mathrm{CFH}$ gene with response to antiVEGF treatment in age-related macular degeneration: a systematic review and meta-analysis. Acta Ophthalmol. 2016;94:334-45.

82. Francis PJ, Zhang H, Dewan A, Hoh J, Klein ML. Joint effects of polymorphisms in the HTRA1, LOC387715/ARMS2, and $\mathrm{CFH}$ genes on AMD in a Caucasian population. Mol Vis. 2008;14:1395-400.

83. Yamashiro K, Mori K, Honda S, Kano M, Yanagi Y, Obana A, Sakurada Y, Sato T, Nagai Y, Hikichi T, Kataoka Y, Hara C, Koyama Y, Koizumi H, Yoshikawa M, Miyake M, Nakata I, Tsuchihashi T, Horie-Inoue K, Matsumiya W, Ogasawara M, Obata R, Yoneyama S, Matsumoto H, Ohnaka M, Kitamei H, Sayanagi K, Ooto S, Tamura H, Oishi A, Kabasawa S, Ueyama K, Miki A, Kondo N, Bessho H, Saito M, Takahashi H, Tan X, Azuma K, Kikushima W, Mukai R, Ohira A, Gomi F, Miyata K, Takahashi K, Kishi S, Iijima H, Sekiryu T, Iida T, Awata T, Inoue S, Yamada R, Matsuda F, Tsujikawa A, Negi A, Yoneya S, Iwata T, Yoshimura N. A prospective multicenter study on genome wide associations to ranibizumab treatment outcome for age-related macular degeneration. Sci Rep. 2017;7:9196.

84. Matsumiya W, Honda S, Yanagisawa S, Miki A, Nagai T, Tsukahara Y. Evaluation of clinical and genetic indicators for the early response to intravitreal ranibizumab in exudative age-related macular degeneration. Pharmacogenomics. 2014;15:833-43.

85. Kuroda Y, Yamashiro K, Miyake M, Yoshikawa M, Nakanishi H, Oishi A, Tamura H, Ooto S, Tsujikawa A, Yoshimura N. Factors associated with recurrence of age-related macular degeneration after anti-vascular endothelial growth factor treatment: a retrospective cohort study. Ophthalmology. 2015;122:2303-10.

86. Cruz-Gonzalez F, Cabrillo-Estevez L, Rivero-Gutierrez V, Sanchez-Jara A, De Juan-Marcos L, Gonzalez-Sarmiento R. 
Influence of CFH, HTRA1 and ARMS2 polymorphisms in the response to intravitreal ranibizumab treatment for wet age-related macular degeneration in a Spanish population. Int J Ophthalmol. 2016;9:1304-9.

87. Chaudhary V, Brent M, Lam WC, Devenyi R, Teichman J, Mak M, Barbosa J, Kaur H, Carter R, Farrokhyar F. Genetic risk evaluation in wet age-related macular degeneration treatment response. Ophthalmologica. 2016;236:88-94.

88. Hu Z, Xie P, Ding Y, Yuan D, Liu Q. Association between variants A69S in ARMS2 gene and response to treatment of exudative AMD: a meta-analysis. Br J Ophthalmol. 2015;99: 593-8.

89. Zhou YL, Chen CL, Wang YX, Tong Y, Fang XL, Li L, Wang ZY. Association between polymorphism rs11200638 in the HTRA1 gene and the response to anti-VEGF treatment of exudative AMD: a meta-analysis. BMC Ophthalmol. 2017;17: 97.

90. Wu M, Xiong H, Xu Y, Xiong X, Zou H, Zheng M, Wang X, Zhou X. Association between VEGF-A and VEGFR-2 polymorphisms and response to treatment of neovascular AMD with anti-VEGF agents: a meta-analysis. $\mathrm{Br} \quad \mathrm{J}$ Ophthalmol. 2017;101:976-84.

91. Lores-Motta L, van Asten F, Muether PS, Smailhodzic D, Groenewoud JM, Omar A, Chen J, Koenekoop RK, Fauser S, Hoyng CB, den Hollander AI, de Jong EK. A genetic variant in NRP1 is associated with worse response to ranibizumab treatment in neovascular age-related macular degeneration. Pharmacogenet Genomics. 2016;26:20-7.

92. Wickremasinghe SS, Xie J, Lim J, Chauhan DS, Robman L, Richardson AJ, Hageman G, Baird PN, Guymer R. Variants in the APOE gene are associated with improved outcome after anti-VEGF treatment for neovascular AMD. Invest Ophthalmol Vis Sci. 2011;52:4072-9.

93. Bakbak B, Ozturk BT, Zamani AG, Gonul S, Iyit N, Gedik S, Yildirim MS. Association of apolipoprotein E polymorphism with intravitreal ranibizumab treatment outcomes in age-related macular degeneration. Curr Eye Res. 2016;41:862-6.

94. Lazzeri S, Orlandi P, Piaggi P, Sartini MS, Casini G, Guidi G, Figus M, Fioravanti A, Di Desidero T, Ripandelli G, Parravano M, Varano M, Nardi M, Bocci G. IL-8 and VEGFR-2 polymorphisms modulate long-term functional response to intravitreal ranibizumab in exudative age-related macular degeneration. Pharmacogenomics. 2016;17:35-9.

95. Francis PJ. The influence of genetics on response to treatment with ranibizumab (Lucentis) for age-related macular degeneration: the Lucentis Genotype Study (an American Ophthalmological Society thesis). Trans Am Ophthalmol Soc. 2011;109:115-56.

96. Riaz M, Lores-Motta L, Richardson AJ, Lu Y, Montgomery G, Omar A, Koenekoop RK, Chen J, Muether P, Altay L, Schick T, Fauser S, Smailhodzic D, van Asten F, de Jong EK, Hoyng CB, Burdon KP, MacGregor S, Guymer RH, den Hollander AI, Baird PN. GWAS study using DNA pooling strategy identifies association of variant rs4910623 in OR52B4 gene with antiVEGF treatment response in age-related macular degeneration. Sci Rep. 2016;6:37924.

97. Lai TY, Liu DT, Chan KP, Luk FO, Pang CP, Lam DS. Visual outcomes and growth factor changes of two dosages of intravitreal bevacizumab for neovascular age-related macular degeneration: a randomized, controlled trial. Retina. 2009;29: $1218-26$

98. Chalam KV, Grover S, Sambhav K, Balaiya S, Murthy RK. Aqueous interleukin-6 levels are superior to vascular endothelial growth factor in predicting therapeutic response to bevacizumab in age-related macular degeneration. J Ophthalmol. 2014;2014:502174.
99. Kepez Yildiz B, Ozdek S, Ergun MA, Ergun S, Yaylacioglu Tuncay F, Elbeg S. CFH Y402H and VEGF polymorphisms and anti-VEGF treatment response in exudative age-related macular degeneration. Ophthalmic Res. 2016;56:132-8.

100. Nassar K, Grisanti S, Elfar E, Luke J, Luke M, Grisanti S. Serum cytokines as biomarkers for age-related macular degeneration. Graefes Arch Clin Exp Ophthalmol. 2015;253:699-704.

101. Lechner J, Chen M, Hogg RE, Toth L, Silvestri G, Chakravarthy $\mathrm{U}, \mathrm{Xu} \mathrm{H}$. Higher plasma levels of complement $\mathrm{C} 3 \mathrm{a}, \mathrm{C} 4 \mathrm{a}$ and C5a increase the risk of subretinal fibrosis in neovascular agerelated macular degeneration: complement activation in AMD. Immun Ageing. 2016;13:4.

102. Kubicka-Trząska A, Wilanska J, Romanowska-Dixon B, Sanak M. Circulating antiretinal antibodies predict the outcome of antiVEGF therapy in patients with exudative age-related macular degeneration. Acta Ophthalmol. 2012;90:e21-4.

103. Dunkelberger JR, Song WC. Complement and its role in innate and adaptive immune responses. Cell Res. 2010;20:34-50.

104. Anderson DH, Radeke MJ, Gallo NB, Chapin EA, Johnson PT, Curletti CR, Hancox LS, Hu J, Ebright JN, Malek G, Hauser MA, Rickman CB, Bok D, Hageman GS, Johnson LV. The pivotal role of the complement system in aging and age-related macular degeneration: hypothesis re-visited. Prog Retin Eye Res. 2010;29:95-112.

105. Yaspan BL, Williams DF, Holz FG, Regillo CD, Li Z, Dressen A, van Lookeren Campagne M, Le KN, Graham RR, Beres T, Bhangale TR, Honigberg LA, Smith A, Henry EC, Ho C, Strauss EC. Targeting factor $\mathrm{D}$ of the alternative complement pathway reduces geographic atrophy progression secondary to age-related macular degeneration. Sci Transl Med. 2017;9(395). https://doi.org/10.1126/scitranslmed.aaf1443.

106. Yehoshua Z, de Amorim Garcia Filho CA, Nunes RP, Gregori G, Penha FM, Moshfeghi AA, Zhang K, Sadda S, Feuer W, Rosenfeld PJ. Systemic complement inhibition with eculizumab for geographic atrophy in age-related macular degeneration: the COMPLETE study. Ophthalmology. 2014;121:693-701

107. Sivaprasad S, Adewoyin T, Bailey TA, Dandekar SS, Jenkins S, Webster AR, Chong NV. Estimation of systemic complement C3 activity in age-related macular degeneration. Arch Ophthalmol. 2007;125:515-9.

108. Scholl HP, Charbel Issa P, Walier M, Janzer S, Pollok-Kopp B, Borncke F, Fritsche LG, Chong NV, Fimmers R, Wienker T, Holz FG, Weber BH, Oppermann M. Systemic complement activation in age-related macular degeneration. PLoS One. 2008;3:e2593.

109. Reynolds R, Hartnett ME, Atkinson JP, Giclas PC, Rosner B, Seddon JM. Plasma complement components and activation fragments: associations with age-related macular degeneration genotypes and phenotypes. Invest Ophthalmol Vis Sci. 2009;50:5818-27.

110. Machalinska A, Dziedziejko V, Mozolewska-Piotrowska K, Karczewicz D, Wiszniewska B, Machalinski B. Elevated plasma levels of $\mathrm{C} 3 \mathrm{a}$ complement compound in the exudative form of age-related macular degeneration. Ophthalmic Res. 2009;42:54-9.

111. Hecker LA, Edwards AO, Ryu E, Tosakulwong N, Baratz KH, Brown WL, Charbel Issa P, Scholl HP, Pollok-Kopp B, SchmidKubista KE, Bailey KR, Oppermann M. Genetic control of the alternative pathway of complement in humans and age-related macular degeneration. Hum Mol Genet. 2010;19:209-15.

112. Stanton CM, Yates JR, den Hollander AI, Seddon JM, Swaroop A, Stambolian D, Fauser S, Hoyng C, Yu Y, Atsuhiro K, Branham K, Othman M, Chen W, Kortvely E, Chalmers K, Hayward C, Moore AT, Dhillon B, Ueffing M, Wright AF. Complement factor $\mathrm{D}$ in age-related macular degeneration. Invest Ophthalmol Vis Sci. 2011;52:8828-34. 
113. Smailhodzic D, Klaver CC, Klevering BJ, Boon CJ, Groenewoud JM, Kirchhof B, Daha MR, den Hollander AI, Hoyng $\mathrm{CB}$. Risk alleles in CFH and ARMS2 are independently associated with systemic complement activation in age-related macular degeneration. Ophthalmology. 2012;119:339-46.

114. Silva AS, Teixeira AG, Bavia L, Lin F, Velletri R, Belfort R Jr, Isaac L. Plasma levels of complement proteins from the alternative pathway in patients with age-related macular degeneration are independent of complement factor $\mathrm{H} \operatorname{Tyr}(4)(0)(2) \mathrm{His}$ polymorphism. Mol Vis. 2012;18:2288-99.

115. van de Ven JP, Nilsson SC, Tan PL, Buitendijk GH, Ristau T, Mohlin FC, Nabuurs SB, Schoenmaker-Koller FE, Smailhodzic D, Campochiaro PA, Zack DJ, Duvvari MR, Bakker B, Paun CC, Boon CJ, Uitterlinden AG, Liakopoulos S, Klevering BJ, Fauser S, Daha MR, Katsanis N, Klaver CC, Blom AM, Hoyng $\mathrm{CB}$, den Hollander AI. A functional variant in the CFI gene confers a high risk of age-related macular degeneration. Nat Genet. 2013;45:813-7.

116. Ansari M, McKeigue PM, Skerka C, Hayward C, Rudan I, Vitart V, Polasek O, Armbrecht AM, Yates JR, Vatavuk Z, Bencic G, Kolcic I, Oostra BA, Van Duijn CM, Campbell S, Stanton CM, Huffman J, Shu X, Khan JC, Shahid H, Harding SP, Bishop PN, Deary IJ, Moore AT, Dhillon B, Rudan P, Zipfel PF, Sim RB, Hastie ND, Campbell H, Wright AF. Genetic influences on plasma $\mathrm{CFH}$ and CFHR1 concentrations and their role in susceptibility to age-related macular degeneration. Hum Mol Genet. 2013;22:4857-69.

117. Sharma NK, Sharma SK, Gupta A, Prabhakar S, Singh R, Anand A. Predictive model for earlier diagnosis of suspected age-related macular degeneration patients. DNA Cell Biol. 2013;32:549-55.

118. Guymer R, Cipriani T, Rittenhouse KD, Lim L, Robman LD, Li W, Wang W, Deng S, Banerjee P. Plasma levels of amyloid beta and other proinflammatory mediators in patients with age-related macular degeneration. Graefes Arch Clin Exp Ophthalmol. 2015;253:1347-54.

119. Schick T, Steinhauer M, Aslanidis A, Altay L, Karlstetter M, Langmann T, Kirschfink M, Fauser S. Local complement activation in aqueous humor in patients with age-related macular degeneration. Eye (Lond). 2017;31(5):810-3. https://doi.org/10. 1038/eye.2016.328.

120. Ristau T, Paun C, Ersoy L, Hahn M, Lechanteur Y, Hoyng C, de Jong EK, Daha MR, Kirchhof B, den Hollander AI, Fauser S. Impact of the common genetic associations of age-related macular degeneration upon systemic complement component C3d levels. PLoS One. 2014;9:e93459.

121. Paun CC, Lechanteur YTE, Groenewoud JMM, Altay L, Schick T, Daha MR, Fauser S, Hoyng CB, den Hollander AI, de Jong EK. A novel complotype combination associates with age-related macular degeneration and high complement activation levels in vivo. Sci Rep. 2016;6:26568. https://doi.org/10.1038/ srep26568.

122. Lores-Motta L, Paun CC, Corominas J, Pauper M, Geerlings MJ, Altay L, Schick T, Daha MR, Fauser S, Hoyng CB, den Hollander AI, de Jong EK. Genome-wide association study reveals variants in $\mathrm{CFH}$ and CFHR4 associated with systemic complement activation: implications in age-related macular degeneration. Ophthalmology. 2018. https://doi.org/10.1016/j.ophtha. 2017.12.023.

123. Falcao DA, Reis ES, Paixao-Cavalcante D, Amano MT, Delcolli MI, Florido MP, Albuquerque JA, Moraes-Vasconcelos D, Duarte AJ, Grumach AS, Isaac L. Deficiency of the human complement regulatory protein factor $\mathrm{H}$ associated with low levels of component C9. Scand J Immunol. 2008;68:445-55.

124. Wagner EK, Raychaudhuri S, Villalonga MB, Java A, Triebwasser MP, Daly MJ, Atkinson JP, Seddon JM. Mapping rare, deleterious mutations in factor $\mathrm{H}$ : association with early onset, drusen burden, and lower antigenic levels in familial AMD. Sci Rep. 2016;6:31531.

125. Triebwasser MP, Roberson ED, Yu Y, Schramm EC, Wagner EK, Raychaudhuri S, Seddon JM, Atkinson JP. Rare variants in the functional domains of complement factor $\mathrm{H}$ are associated with age-related macular degeneration. Invest Ophthalmol Vis Sci. 2015;56:6873-8.

126. Caprioli J, Noris M, Brioschi S, Pianetti G, Castelletti F, Bettinaglio P, Mele C, Bresin E, Cassis L, Gamba S, Porrati F, Bucchioni S, Monteferrante G, Fang CJ, Liszewski MK, Kavanagh D, Atkinson JP, Remuzzi G. Genetics of HUS: the impact of MCP, CFH, and IF mutations on clinical presentation, response to treatment, and outcome. Blood. 2006;108:1267-79.

127. Fukumori Y, Yoshimura K, Ohnoki S, Yamaguchi H, Akagaki $\mathrm{Y}$, Inai S. A high incidence of C9 deficiency among healthy blood donors in Osaka, Japan. Int Immunol. 1989;1:85-9.

128. Geerlings MJ, Kremlitzka M, Bakker B, Nilsson SC, Saksens NT, Lechanteur YT, Pauper M, Corominas J, Fauser S, Hoyng CB, Blom AM, de Jong EK, den Hollander AI. The functional effect of rare variants in complement genes on $\mathrm{C} 3 \mathrm{~b}$ degradation in patients with age-related macular degeneration. JAMA Ophthalmol. 2017;135:39-46.

129. Geerlings MJ, de Jong EK, den Hollander AI. The complement system in age-related macular degeneration: a review of rare genetic variants and implications for personalized treatment. Mol Immunol. 2017;84:65-76.

130. Le Meur G, Lebranchu P, Billaud F, Adjali O, Schmitt S, Bezieau S, Pereon Y, Valabregue R, Ivan C, Darmon C, Moullier P, Rolling F, Weber M. Safety and long-term efficacy of AAV4 gene therapy in patients with RPE65 Leber congenital amaurosis. Mol Ther. 2018;26(1):256-68. https://doi.org/10. 1016/j.ymthe.2017.09.014.

131. Filleur S, Nelius T, de Riese W, Kennedy RC. Characterization of PEDF: a multi-functional serpin family protein. J Cell Biochem. 2009;106:769-75.

132. Campochiaro PA, Nguyen QD, Shah SM, Klein ML, Holz E, Frank RN, Saperstein DA, Gupta A, Stout JT, Macko J, DiBartolomeo R, Wei LL. Adenoviral vector-delivered pigment epithelium-derived factor for neovascular age-related macular degeneration: results of a phase I clinical trial. Hum Gene Ther. 2006;17:167-76.

133. He Y, Smith SK, Day KA, Clark DE, Licence DR, CharnockJones DS. Alternative splicing of vascular endothelial growth factor (VEGF)-R1 (FLT-1) pre-mRNA is important for the regulation of VEGF activity. Mol Endocrinol. 1999;13:537-45.

134. Heier JS, Kherani S, Desai S, Dugel P, Kaushal S, Cheng SH, Delacono C, Purvis A, Richards S, Le-Halpere A, Connelly J, Wadsworth SC, Varona R, Buggage R, Scaria A, Campochiaro PA. Intravitreous injection of AAV2-sFLT01 in patients with advanced neovascular age-related macular degeneration: a phase 1, open-label trial. Lancet. 2017;390:50-61.

135. Constable IJ, Pierce CM, Lai CM, Magno AL, Degli-Esposti MA, French MA, McAllister IL, Butler S, Barone SB, Schwartz SD, Blumenkranz MS, Rakoczy EP. Phase 2a randomized clinical trial: safety and post hoc analysis of subretinal rAAV.sFLT-1 for wet age-related macular degeneration. EBioMed. 2016;14:168-175.

136. O'Reilly MS, Holmgren L, Shing Y, Chen C, Rosenthal RA, Moses M, Lane WS, Cao Y, Sage EH, Folkman J. Angiostatin: a novel angiogenesis inhibitor that mediates the suppression of metastases by a Lewis lung carcinoma. Cell. 1994;79:315-28.

137. O'Reilly MS, Boehm T, Shing Y, Fukai N, Vasios G, Lane WS, Flynn E, Birkhead JR, Olsen BR, Folkman J. Endostatin: an endogenous inhibitor of angiogenesis and tumor growth. Cell. 1997;88:277-85. 
138. Campochiaro PA, Lauer AK, Sohn EH, Mir TA, Naylor S, Anderton MC, Kelleher M, Harrop R, Ellis S, Mitrophanous KA. Lentiviral vector gene transfer of endostatin/angiostatin for Macular Degeneration (GEM) Study. Hum Gene Ther. 2017;28:99-111.

139. Cashman SM, Gracias J, Adhi M, Kumar-Singh R. Adenovirusmediated delivery of factor $\mathrm{H}$ attenuates complement $\mathrm{C} 3$ induced pathology in the murine retina: a potential gene therapy for age-related macular degeneration. $J$ Gene Med. 2015; 17:229-43.

140. Schwartz SD, Hubschman JP, Heilwell G, Franco-Cardenas V, Pan CK, Ostrick RM, Mickunas E, Gay R, Klimanskaya I, Lanza R. Embryonic stem cell trials for macular degeneration: a preliminary report. Lancet. 2012;379:713-20.

141. Schwartz SD, Regillo CD, Lam BL, Eliott D, Rosenfeld PJ, Gregori NZ, Hubschman JP, Davis JL, Heilwell G, Spirn M, Maguire J, Gay R, Bateman J, Ostrick RM, Morris D, Vincent M, Anglade E, Del Priore LV, Lanza R. Human embryonic stem cell-derived retinal pigment epithelium in patients with age-related macular degeneration and Stargardt's macular dystrophy: follow-up of two open-label phase $1 / 2$ studies. Lancet. 2015;385:509-16.

142. Song WK, Park KM, Kim HJ, Lee JH, Choi J, Chong SY, Shim SH, Del Priore LV, Lanza R. Treatment of macular degeneration using embryonic stem cell-derived retinal pigment epithelium: preliminary results in Asian patients. Stem Cell Reports. 2015;4:860-72.

143. Mandai M, Watanabe A, Kurimoto Y, Hirami Y, Morinaga C, Daimon T, Fujihara M, Akimaru H, Sakai N, Shibata Y, Terada M, Nomiya Y, Tanishima S, Nakamura M, Kamao H, Sugita S, Onishi A, Ito T, Fujita K, Kawamata S, Go MJ, Shinohara C, Hata KI, Sawada M, Yamamoto M, Ohta S, Ohara Y, Yoshida K, Kuwahara J, Kitano Y, Amano N, Umekage M, Kitaoka F, Tanaka A, Okada C, Takasu N, Ogawa S, Yamanaka S, Takahashi M. Autologous induced stem-cell-derived retinal cells for macular degeneration. N Engl J Med. 2017;376:1038-46.

144. Garber K. RIKEN suspends first clinical trial involving induced pluripotent stem cells. Nat Biotechnol. 2015;33:890-1.

145. Cyranoski D. Japanese man is first to receive 'reprogrammed' stem cells from another person. Nature. 2017. https://doi.org/10. 1038/nature.2017.21730.

146. Kuriyan AE, Albini TA, Townsend JH, Rodriguez M, Pandya HK, Leonard RE 2nd, Parrott MB, Rosenfeld PJ, Flynn HW Jr, Goldberg JL. Vision loss after intravitreal injection of autologous "stem cells" for AMD. N Engl J Med. 2017;376:1047-53.

147. Kersten E, Paun CC, Schellevis RL, Hoyng CB, Delcourt C, Lengyel I, Peto T, Ueffing M, Klaver CCW, Dammeier S, den Hollander AI, de Jong EK. Systemic and ocular fluid compounds as potential biomarkers in age-related macular degeneration. Surv Ophthalmol. 2018;63(1):9-39. https://doi.org/10.1016/j. survophthal.2017.05.003.

148. Sardell RJ, Persad PJ, Pan SS, Whitehead P, Adams LD, Laux RA, Fortun JA, Brantley MA Jr, Kovach JL, Schwartz SG, Agarwal A, Haines JL, Scott WK, Pericak-Vance MA. Progression rate from intermediate to advanced age-related macular degeneration is correlated with the number of risk alleles at the CFH locus. Invest Ophthalmol Vis Sci. 2016;57:6107-15.

149. Park JH, Gail MH, Weinberg CR, Carroll RJ, Chung CC, Wang Z, Chanock SJ, Fraumeni JF Jr, Chatterjee N. Distribution of allele frequencies and effect sizes and their interrelationships for common genetic susceptibility variants. Proc Natl Acad Sci USA. 2011;108:18026-31.

150. Amoaku WM, Chakravarthy U, Gale R, Gavin M, Ghanchi F, Gibson J, Harding S, Johnston RL, Kelly SP, Lotery A, Mahmood S, Menon G, Sivaprasad S, Talks J, Tufail A, Yang Y.
Defining response to anti-VEGF therapies in neovascular AMD. Eye (Lond). 2015;29:721-31.

151. Gemenetzi M, Lotery AJ, Patel PJ. Risk of geographic atrophy in age-related macular degeneration patients treated with intravitreal anti-VEGF agents. Eye (Lond). 2017;31:1-9.

152. Nakata I, Yamashiro K, Nakanishi H et al. VEGF gene polymorphism and response to intravitreal bevacizumab and triple therapy in age-related macular degeneration. Jpn J Ophthalmol. 2011;55(5):435-43. https://doi.org/10.1007/s10384-011-0061-z.

153. Wang VM, Rosen RB, Meyerle CB, Kurup SK, Ardeljan D, Agron E, Tai K, Pomykala M, Chew EY, Chan CC, Tuo J. Suggestive association between PLA2G12A single nucleotide polymorphism rs2285714 and response to anti-vascular endothelial growth factor therapy in patients with exudative agerelated macular degeneration. Mol Vis. 2012;18:2578-85.

154. Boltz A, Ruiß M, Jonas JB, Tao Y, Rensch F, Weger M, Garhöfer G, Frantal S, El-Shabrawi Y, Schmetterer L. Role of vascular endothelial growth factor polymorphisms in the treatment success in patients with wet age-related macular degeneration. Ophthalmology. 2012;119(8):1615-20. https://doi.org/ 10.1016/j.ophtha.2012.02.001

155. Abedi F, Wickremasinghe S, Richardson AJ, Makalic E, Schmidt DF, Sandhu SS, Baird PN, Guymer RH. Variants in the VEGFA gene and treatment outcome after anti-VEGF treatment for neovascular age-related macular degeneration. Ophthalmology. 2013;120(1):115-21. https://doi.org/10.1016/j.ophtha.2012. 10.006.

156. Zhao L, Grob S, Avery R, Kimura A, Pieramici D, Lee J, Rabena M, Ortiz S, Quach J, Cao G, Luo H, Zhang M, Pei M, Song Y, Tornambe P, Goldbaum M, Ferreyra H, Kozak I, Zhang $\mathrm{K}$. Common variant in VEGFA and response to anti-VEGF therapy for neovascular age-related macular degeneration. Curr Mol Med. 2013;13(6):929-34.

157. Hagstrom SA, Ying GS, Pauer GJ, Huang J, Maguire MG, Martin DF; CATT Research Group. Endothelial PAS domaincontaining protein 1 (EPAS1) gene polymorphisms and response to anti-VEGF therapy in the comparison of AMD treatments trials (CATT). Ophthalmology. 2014;121(8):1663-4.e1. https:// doi.org/10.1016/j.ophtha.2014.02.025.

158. Hermann MM, van Asten F, Muether PS, Smailhodzic D, Lichtner P, Hoyng CB, Kirchhof B, Grefkes C, den Hollander AI, Fauser S. Polymorphisms in vascular endothelial growth factor receptor 2 are associated with better response rates to ranibizumab treatment in age-related macular degeneration. Ophthalmology. 2014;121(4):905-10. https://doi.org/10.1016/j. ophtha.2013.10.047.

159. Hagstrom SA, Ying GS, Pauer GJ, Sturgill-Short GM, Huang J, Maguire MG, Martin DF; Comparison of Age-Related Macular Degeneration Treatments Trials (CATT) Research Group. VEGFA and VEGFR2 gene polymorphisms and response to anti-vascular endothelial growth factor therapy: comparison of age-related macular degeneration treatments trials (CATT). JAMA Ophthalmol. 2014;132(5):521-7. https://doi.org/10.1001/ jamaophthalmol.2014.109.

160. Cruz-Gonzalez F, Cabrillo-Estévez L, López-Valverde G, Cieza-Borrella C, Hernández-Galilea E, González-Sarmiento R. Predictive value of VEGF A and VEGFR2 polymorphisms in the response to intravitreal ranibizumab treatment for wet AMD. Graefes Arch Clin Exp Ophthalmol. 2014;252(3):469-75. https://doi.org/10.1007/s00417-014-2585-7.

161. Veloso CE, de Almeida LN, Recchia FM, Pelayes D, Nehemy MB. VEGF gene polymorphism and response to intravitreal ranibizumab in neovascular age-related macular degeneration. Ophthalmic Res. 2014;51(1):1-8. https://doi.org/10.1159/ 000354328 
162. Hagstrom SA, Ying GS, Maguire MG, Martin DF; CATT Research Group, Gibson J, Lotery A, Chakravarthy U; IVAN Study Investigators. VEGFR2 gene polymorphisms and response to anti-vascular endothelial growth ractor therapy in age-related macular degeneration. Ophthalmology. 2015;122(8):1563-8. https://doi.org/10.1016/j.ophtha.2015.04. 024.

163. Bardak H, Bardak Y, Ercalik Y, Turkseven Kumral E, Imamoglu S, Gunay M, Ozbas H, Bagci O. Effect of ARMS2 gene polymorphism on intravitreal ranibizumab treatment for neovascular age-related macular degeneration. Genet Mol Res. 2016;15(4). https://doi.org/10.4238/gmr15049164.

164. Rakoczy EP, Lai CM, Magno AL, Wikstrom ME, French MA, Pierce CM, Schwartz SD, Blumenkranz MS, Chalberg TW, Degli-Esposti MA, Constable IJ. Gene therapy with recombinant adeno-associated vectors for neovascular age-related macular degeneration: 1 year follow-up of a phase 1 randomised clinical trial. Lancet. 2015;386(10011):2395-403. https://doi.org/10 . 1016/S0140-6736(15)00345-1.

165. Constable IJ, Lai CM, Magno AL, French MA, Barone SB, Schwartz SD, Blumenkranz MS, Degli-Esposti MA, Rakoczy EP. Gene therapy in neovascular age-related macular degeneration: three-year follow-up of a phase 1 randomized dose escalation trial. Am J Ophthalmol. 2017;177:150-8. https://doi. org/10.1016/j.ajo.2017.02.018.

166. Ho AC, Chang TS, Samuel M, Williamson P, Willenbucher RF, Malone T. Experience with a subretinal cell-based therapy in patients with geographic atrophy secondary to age-related macular degeneration. Am J Ophthalmol. 2017;179:67-80. https://doi.org/10.1016/j.ajo.2017.04.006. 